\title{
Tackling the Subaltern Quandary: Marketing Systems of Dignity
}

\author{
Sujit Raghunathrao Jagadale,' Djavlonbek Kadirov, ${ }^{2}$ \\ and Debojyoti Chakraborty ${ }^{3}$
}

\begin{abstract}
The subaltern quandary refers to the failure of a fast-growing economy to improve the abysmal living conditions of marginalized groups. To gain a better insight into this issue, we investigate the subaltern group's experiences of marketing systems in the context of neo-liberal reforms in rural India. The qualitative analysis of subaltern narratives shows that subaltern experiences are shaped by marketization processes that imbue market relations with new stylized meanings of dignity. Despite these meanings perpetuating limited and distorted constructions, subalterns use them, exemplified in their attempts to minimize their perceived dissimilarity to other marketing system actors, in order to gain access to predominant, albeit flawed, marketing systems. Thus, the status quo is rarely challenged. This research suggests that the subaltern quandary can only be resolved when market development initiatives take human worth as a main goal, while subalterns are empowered with market system creation, design and governance capabilities.
\end{abstract}

\section{Keywords}

dignity, apophatic dignity, dignification, marketing systems, neoliberalism, subaltern

\begin{abstract}
All sisters are sitting together in courtyard and pleading to their husbands,

Oh, husband! Do not drink liquor, my heart bleeds seeing my son sleeping hungry!

Rich man's son eats colorful fruits, grapes, and pomegranates,

Oh, husband! My heart bleeds on seeing my son eating salt and bread!

Rich man's son studies in district school and college,

Oh, husband! My heart bleeds on seeing my son playing the stick-game Gulli danda!

Rich man's son wears shirt, pants and puts a tie,

Oh, husband! My heart bleeds on seeing my son wearing torn rags...
\end{abstract}

(A song performed by a group of informants in an Indian village)

The great Indian poverty debate still fascinates many scholars in different fields (Deaton and Kozel 2005; Deaton and Drèze 2002; Drèze and Sen 2013; Lal 2001; Patnaik 2013; Sen and Himanshu 2004; Shrivastava and Kothari 2014; Swaminathan 2000; Varman and Costa 2008; Varman, Skalen, and Belk 2012). Despite its many variations, this debate underscores a general predicament, i.e. the subaltern quandary, the essence of which is aptly captured by Drèze and Sen (2013) in the following quote: "The history of world development offers few other examples, if any, of an economy growing so fast for so long with such limited results in terms of reducing human deprivations" (p. viii). Marketing scholars including macromarketers contributed to this debate by exploring subaltern market actors in the context of emerging Indian markets, while focusing on subaltern empowerment and healthcare systems (Varman and Vikas 2007b), micro-interactive market action (Viswanathan et al. 2009), marketization and consumptionscapes (Varman and Belk 2008, 2012; Vikas, Varman, and Belk 2015), subaltern consumption behaviour (Chaudhuri 2010; Eckhardt and Mahi 2012; Jaiswal and Gupta 2015), marketing intoxicants to minors (Vikas and Varman 2007), and public policy and subaltern marketing initiatives (Varman, Skalen, and Belk 2012; Viswanathan et al. 2012).

We delineate three broad macromarketing approaches that have been proposed to tackle the subaltern quandary: the bottom-of-the-pyramid perspective (Prahalad 2010; Prahalad and Hammond 2002; Hart and Prahalad 2002; also see Bonsu and

\footnotetext{
'Institute of Rural Management Anand, India

${ }^{2}$ Victoria Business School, Victoria University of Wellington, Wellington, New Zealand

${ }^{3}$ Samaj Pragati Sahyog, Dewas, Madhya Pradesh, India

\section{Corresponding Author:}

Sujit Raghunathrao Jagadale, Institute of Rural Management Anand, India, Near NDDB, Agricultural University Road, Anand, Gujarat 38800I, India.

Email: sujit.jagadale@gmail.com
} 
Polsa 2011), the moral economy perspective (Varman and Costa 2008; Belk 2010), and the capabilities economy perspective (Sen 1985, 1999). Despite drawing strong criticism from both researchers and practitioners, these perspectives have been successful in selected areas and have informed a large number of development initiatives. Yet, we submit that these perspectives, due to their broad scope and various foci, overlooked subalterns' lived experiences, aspirations, and practices instrumental in shaping their humanity.

The current investigation aims to probe this avenue for research. In doing this, we focus on the following points in our analysis: how market system actors become subaltern, possible reasons for the emergence of dignity experiences in the context of market relations, and the ways dignity is experienced and/or problematized by subalterns within marketing systems. We find that the purposeful perpetuation of a marketized simulacrum of archaic dignification practices by the elite reverberates in subalterns' lived experiences as apophatic dignity. Subalterns make attempts to flee such experiences by minimizing their dissimilitude to the "other", which paradoxically leads to their strong desire to assimilate into the same dysfunctional market structure. As a consequence, the constancy of a problematic structure, i.e. market relations based on the archaic conception of dignity, is rarely challenged, although some subalterns may individually succeed in their quest for assimilation.

This investigation contributes to the macromarketing development literature (Mittelstaedt et al. 2014) by 1) highlighting human dignity as a major factor that needs to be taken into account in development initiatives, especially in the context of subaltern issues; 2) scrutinizing the capacity of the three aforementioned macromarketing approaches for resolving the subaltern quandary in the light of the findings; 3 ) offering an interpretive framework of dignity-based marketing system processes in the subaltern context; and 4) extending a number of recommendations with regard to fostering the subaltern capability of shaping dignity-based marketing systems. Also, we extend marketing systems theory, specifically the MAS theory (Layton 2015), by locating dignity related processes and mechanisms at the heart of marketing systems emergence, formation, and adaptive change. In accomplishing this task, we first provide a brief overview of the research context and related theoretical considerations, then describe the qualitative method and procedures, and thereafter present the results of our interpretation of the collected qualitative material. The final section offers the discussion of the findings and implications for macromarketers and public policy makers.

\section{Research Context and Theoretical Considerations}

\section{The Subaltern Quandary and Neoliberalism in India}

The concept "subaltern" refers to impoverished, marginalized, and underprivileged layers of the population living under the condition of life-threatening poverty (Varman and Belk 2008;
Varman and Vikas 2007a, 2007b; Vikas, Varman, and Belk 2015). The subaltern group is constituted of the working class and peasantry who have command of no significant resources (e.g. human, social and economic capital) or minimal resources (e.g. labor-power) that are perhaps just enough for bare survival (Vikas, Varman, and Belk 2015). Subaltern households tend to live in abysmal material conditions, and predominantly at the margins of society. The powerlessness, vulnerability, and lack of resources attributed to this group is so striking that they have long been ignored by both business thinkers and practitioners (Chaudhuri 2010; Prahalad 2010). The subaltern population in India is estimated to be 924.1 million people, constituting a total market of USD 1.2 trillion (Hammond et al. 2002). The official government data shows that the rural India represents an informal economy of 92 million households, where $51.18 \%$ of them cite casual manual labor as their main source of income, while 54.1 million households $(30.10 \%)$ derive their main income from land cultivation and farming. In general, the census data from 2011 show that in 164.9 million Indian households (including $91.7 \%$ of the rural households) the highest earning member earns less than $\$ 66.22$ per month, while 134 million households' main breadwinner earns less than $\$ 33.11$ per month. These data approximately coincide with the $\$ 1.08$ and $\$ 2.16$ a day poverty threshold as defined by Banerjee and Duflo (2007).

Narrowly defined market development policies, the "dismal" governance as defined by Drèze and Sen (2013), contributed to, rather than eradicating, the appalling economic conditions of the subaltern group. Driven by the maxim that human well-being would be best served by free markets and minimum state intervention (Joseph 2007; Harvey 2007; Clarke 2004; Smith 2007), India introduced a number of neoliberal economic policies in the early 1990s. In particular, the structural adjustment program (SAP) initiated in 1991 had economic liberalization, privatization and globalization (LPG) as its elements and became the most effective program in terms of economic growth (Patnaik and Chandrasekhar 1995). However, since its inception, the economic reform led to relatively weak state welfare support, a substantial reduction in subsidies, intensive privatization, and unconditional support for large corporations (Patnaik 2007a). Although these reforms benefited the middle class and the corporate sector to a great extent, the poor and the rural world bore the brunt of the government's modified policy priorities (Drèze and Sen 2013; Maiorano 2014). The state's spending on subsidies and welfare programs have reduced considerably in the last couple of decades (Ghosh and Chandrasekhar 2000; Chossudovsky 1997; Kurien 1995). This has effectively led to the higher levels of poverty and inequality (Ghosh and Chandrasekhar 2000; Patnaik 2004; Swaminathan 2000; Sen and Himanshu 2004). For example, the state support to agriculture significantly declined, which further aggravated the conditions of the poor (Sole 2014).

Some commentators note that neoliberalism entails dismantling of institutions that are based on egalitarian distributive measures (Harvey 2007). Discussing the impact of the state's withdrawal of support for small farmers and the rural India, 
Sainath (2009) noted that the most significant impact of neoliberalism, perhaps as an externality, was the relentless dismantling of the largest market institution of smallholder farmers in the world. Investments in the rural economy steadily decreased, in one estimate, by INR 30 billion (USD 6 billion) per year (Sainath 2009). As existing few protections for small farmers had vanished, a whole new class of "economic predators" appeared in the countryside. For instance, the vacuum created by the state's withdrawal was filled by MNCs which dominated the seeds supply industry and were driven by a motivation to undermine indigenous cultivations systems (Sainath 2009). Similarly, many small farmers fell prey to mining companies, while the closure of many nationalized bank branches opened a way for the newly emerging "financier" class with predatory moneylending practices. In the last two decades, the countryside has witnessed about 350 thousand people committing suicide; many of them were small farmers who chose to stay in agriculture (Shrivastava and Kothari 2014).

Although India climbed rapidly up the ladder of economic growth, it has fallen relatively behind in general quality-of-life indicators. In fairness, we must note that some aspects of the subaltern group's life improved, but such improvements were excruciatingly slow, thus failing to significantly alter the group's abysmal living conditions (Drèze and Sen 2013). India's average annual GDP growth and the average income growth per capita have been impressive, at $6.3 \%$ and $4.6 \%$ respectively in 1990-2015 (Kumar 2016b). However, the proportion of urban population accessing less than 2,100 calories per person per day, which is the official benchmark of poverty, increased from 57\% in 1993-1994 to 65\% in 2011-2012. Likewise, the percentage of rural population unable to access 2,100 calories per person per day increased from $58.5 \%$ in 1993-1994 to $68 \%$ in 2011-2012 (Patnaik 2013).

The urban population below the poverty line increased from $57 \%$ in $1993-1994$ to $65.5 \%$ in $2004-2005$. Among the rural population, this proportion has apparently gone up from $74.5 \%$ to $87 \%$ in the same period (Patnaik 2007b). Furthermore, the level of prices for essential services like education and healthcare increased owing to widespread privatization, while the lack of growth in full employment has become apparent. Such deterioration, in general, can perhaps be attributed to population growth rates as well, however, what is certain is that neoliberalism has at least failed to reverse such trends. The dilemma was that the decline in quality-of-life indicators was accompanied by rapidly increasing the abundance of goods and services (Varman and Belk 2008). Unfortunately, at least in the Indian case the promised "trickledown" did not realize, while the vast population was left at the mercy of ever expanding and intensifying markets (Kurien 1995; Varman and Belk 2008).

Varman, Skalen, and Belk (2012) argue that in the rural India the individual entitlement, defined by Sen (1984, p. 452 ) as a set of alternative commodities bundles available through legal means available in society (e.g. trade opportunities, entitlement vis-à-vis state), has decreased due to the introduction of policy based limitations to the state's welfare functions. Hence, neoliberalism led to the systematic erosion of public welfare and provisioning institutions (Varman, Skalen, and Belk 2012; Varman and Vikas 2007b).

\section{The Caste System and the Subaltern Market Actor}

Indian society transcends the rigid economic class analysis (Lal 2001). There are many bases of stratification in the Indian society including social status, caste, class, gender, age, wealth, employment and so on, the factors that in their intersection give rise to 'social and political hegemonic discourses' as the complex foundation for subaltern stratification (Spivak 1988). The caste system and the remnants of the related Jajmani system represent two major macro-structures that exacerbate the subaltern quandary (Vikas, Varman, and Belk 2015).

The caste system is a complex societal stratification institution that is based on the division of people into distinct hereditary groups, i.e. castes. The system reinforces a 'hierarchy' of castes which are distinctively a) separated from each other in various milieus, e.g. marriage, contact, food consumption; b) divided in terms of labor, and c) ranked in terms superiority/ inferiority (Dumont 1970). The caste system embodies normatively imposed unequal rights in all aspects of life (Thorat 2010). In the region under focus, the caste hierarchy includes Brahmins followed by Thakurs as top castes. There remains an ongoing political tussle between these castes to claim supremacy. They are followed by many castes (e.g. Kurmi, Yadav, Lohar, and Muslims) involved in agriculture that are classified as the Other Backward Class (OBC). The Chamar caste is the lowest in the hierarchy and classified as a scheduled caste (SC). Other SC castes were Nishaad, Paswan, Sonkar, and Khuswaha.

In pre-modern times, economic relations were governed by Jajmani, which involved patronage-based provisioning. The Jajmani system refers to a religious-economic institution in which landholding upper castes, zamindars, exchanged food for varied services of lower castes (Kumar 2016a). The main features of Jajmani were the use of hereditary relationships to affirm the established division of labour, the closed premonetary system of privileged redistribution, and the cycles of (re)payment in kind that is spread over the year (e.g. harvest time, festivals, and major family ceremonies) (Dumont 1970). The system was highly exploitative, as zamindars expected, by their hereditary right, to be served by low caste workers (Vikas, Varman, and Belk 2015). Although the Jajmani system is not operational in its conventional form now, its sociocultural norms are still deeply engrained on how contemporary exchanges are conducted (Srinivas 2003).

The rise of caste emancipation movements and the deepening of capitalism, in the form of neoliberal marketization in the 20th century, challenged the privileged position/status accrued by the high caste groups. Vikas, Varman, and Belk (2015) show that people who are forced to forgo their privileged status tried their best to retain their positions by hindering free exchange, monopolizing markets, or re-configuring value systems to recast their superiority. The caste system involves exclusion 
and discrimination in both market and non-market relations, including access to markets (Ray 2011; Roy 2012).

Although recent market-driven changes have affected the fortunes of many, the disparity between the life conditions of the low caste and the high caste continued to grow (Thorat 2002; Kijima 2006; Borooah, Dubey, and Iyer 2007). Lower castes still lag behind in a number of human development indicators like education, health, and income (Thorat 2010). Moreover, there has been a clear evidence of caste-based discrimination in access to work/livelihood (Madheswaran and Attewel 2007; Thorat and Attewell 2007) and thus access to markets, specifically in rural North India (Ito 2009). Despite the caste system or caste based discriminations being officially outlawed in India, the economic circumstances of lower and upper castes continue to differ substantially (Ito 2009; Thorat 2002), thus intensifying the subaltern quandary.

Next, we briefly discuss three different economic development approaches proposed by influential market thinkers to specifically address the subaltern quandary in the Indian context. As these approaches are based on restructuring markets and marketing systems, we believe that this domain pertains to macromarketing. In the spirit of qualitative investigation, we offer a succinct overview of the approaches in order to delimit the scope of this qualitative inquiry.

\section{Macromarketing Solutions}

BoP. The bottom-of-the-pyramid perspective (BoP) represents an attempt to address the neoliberalist oversight by drawing the attention of scholars and practitioners to the potential, if not hypothetical, rewards of developing subaltern markets (Prahalad 2010). The term 'Bottom of Pyramid' was first coined by Roosevelt in 1932 (Singh 2015), and the first attempt to explicitly define the segment came from Prahalad and his co-authors (Prahalad and Hammond 2002; Hart and Prahalad 2002). The most popular metric to dissect the tiers of the 'pyramid' has so far been income (Rangan, Chu, and Petkoski 2011). In that, the variations like 'extremely poor', less than $\$ 1.08$ income per capita per person per day using the 1993 purchasing power parity as the benchmark, and 'poor' ( $\$ 2.16$ a day) have been used (Banerjee and Duflo 2007). Other direct measures such as total per capita income at or below $\$ 1,500$ or $\$ 2,000$ per annum also exist (Kolk, Rivera-Santos, and Rufín 2014). Using a definition of income below $\$ 3,000$ in purchasing power, it has been estimated that there are 4 billion people at the base of the economic pyramid $(\mathrm{BoP})$ worldwide who constitute the USD 5 trillion global consumer market.

BoP invests full trust, as well as hope, in neo-liberal reforms in which profit-oriented private enterprises are expected to address the needs of disenfranchised billions surviving at the bottom of the economic pyramid (Prahalad 2010; Hart and Prahalad 2002). BoP's central thesis is simplistically alluring: profit maximization would result in poverty alleviation subject to global corporations innovatively exploiting existing business opportunities.
Moral economy. Another macromarketing solution to the 'subaltern' quandary draws on the moral economy perspective (Varman and Costa 2008; Varman and Vikas 2007; Vikas, Varman, and Belk 2015; Weinberger and Wallendorf 2012). The moral economy perspective is an umbrella term that covers various perspectives that view markets as socially-embedded practices and mechanisms of provisioning (Booth 1994; Fisk 1974; Granovetter 1985; Polanyi (2001) [1944]; Belk 2010).

Drawing on the substantive analysis by Polanyi ((2001) [1944]), which highlights the importance of both market and non-market mechanisms of provisioning such as reciprocity, redistribution, and exchange, macromarketing researchers proposed various ways in which fundamentally social practices (e.g. gifting, sharing) could complement market practices in improving the situation of the poor (Varman and Costa 2008). From this perspective, market exchanges are seen to be embedded in encompassing non-market domains of relationships- symbolism, gifting, sharing, communing and mutual support (Belk 2010; Weinberger and Wallendorf 2012). Hence, the solution seemed to be in fostering and enhancing traditional, local, indigenous provisioning mechanisms in addition to the newly introduced modern market mechanisms.

The moral economy proponents critiqued the rise in 'economism' seen as attaching more importance to economic goals over societal goals (Varman and Belk 2008), and excessive 'consumerism' in the wake of neoliberal policies which led to the decline in social ties and dilution in the kin-based systems of exchange (Varman and Belk 2008). Reciprocity was seen as a major way of provisioning, while ever-decreasing dependence on kinship structures was viewed as a negative trend. Researchers argue that although free markets enhance consumer choice, zealous neoliberal support restricts consumer power because of the limited participation of public institutions in the governance of exchanges (Chossudovsky 1997; Kurien 1995) and weakened non-market modes of participation (Kurien 1995; Patnaik 2004; Patnaik 2007; Swaminathan 2000; Sainath 2009; Varman and Belk 2008). Therefore, most recommendations center around attaining a balanced development of both market and non-market spheres of marketing systems (Kadirov, Varey, and Wolfenden 2016).

Capabilities economy. Poverty can only be overcome if the poor succeed in developing capabilities which would enable them to convert resources including market goods (BoP's emphasis) and provisioning processes (Moral Economy's emphasis) into effective outcomes for themselves (Sen 1985, 1999). The capability approach proposed by Sen (1985) questions both the BoP assumption that better access to commercial goods is a sufficient condition for attaining good life and the moral economy's focus on accumulating resources (accessed via both market and non-market provisioning) with no concern over how these resources are converted into valuable outcomes. While eschewing the effectiveness of resourcism (i.e. well-being is equated to fair resource distribution) and utilitarianism (i.e. well-being is equated to psychological constructs such as happiness, pleasure, desire fulfillment), Sen (1999) argued that the focus on 
economic development with a view to improving the living conditions of the poor must be on enhancing individual capabilities "to achieve the kind of lives we have reason to value" (p. 10). Sen (1999) believes that any solution to poverty should be based on identifying key 'functionings' in a society (what individuals may value 'doing' or 'being' such as being adequately nourished, having self-respect, or enjoying good health), and then fostering 'capabilities', i.e. the ability to achieve these functionings.

In their book An Uncertain Glory: India and Its Contradictions, Drèze and Sen (2013) directly tackle the persisting poverty issue in India through the capability approach lenses. The authors argue that the story of fast economic growth in India is illusory, as it does not address social inequality trends. The authors further argue that Indian policy makers have ignored the basic needs and capabilities of people, particularly that of the poor and women. The basic need for dignified life has been neglected, in turn negating social justice to the impoverished.

The main problem, as highlighted by Drèze and Sen, is a lack of attention for the essential need provisioning for the poor to help them to build lives they value. The authors indicate that India cannot move forward without significant investment in public services (e.g. health, education) and infrastructure (e.g. clean drinking water, sanitation, electricity). In their view, the solution lies in "ambitious social programs" driven by all citizens including the ruling elite, the middle class, and generally wider publics, to create significant investments in public hygiene, utilities, infrastructure, education, healthcare, and transportation. They argue that economic growth is meaningless without the redistribution of its benefits to the underprivileged and make a case for the development of essential capabilities.

\section{The MAS Theory and the Concept of Dignity}

To augment the aforementioned macromarketing approaches, we draw on the mechanisms, actions and structure (MAS) framework (Layton 2015) and the concept of dignity (Adler 1967; Egonsson 2012; Kant (2002) [1785]; Nussbaum 2011; Varey and Pirson 2014). The MAS framework teaches that effective marketing systems, representing socially embedded networks of value creation, form, grow, and adaptively change under the impact of 1) the social mechanisms of co-evolution and co-operation among individuals/entities with differential endowments (e.g. beliefs, empathy, skills, abilities) which lead to the secondary social mechanisms of market exchange; 2) action fields in which market participants interact in the pursuit of perceived advantage; and 3) tangible and intangible structures, functions and outcomes. From this perspective, a marketing system is a much broader and richer concept than the neoliberal notion of 'the market system' which denotes a locus of economic exchanges (Polanyi (2001) [1944]). A marketing system is a complex technology of provisioning, whereas a market system is simply a small part of it (Layton 2009). Within the MAS framework, the subaltern issue is treated as 'marketing system failure' (Layton 2015), whereby a group of citizens is barred from creating effective outcomes for themselves due to being transformed into 'a means' (via marginalization and discrimination) while their endowments are demeaned for the sake of fueling traditionally established social mechanisms (Vikas, Varman, and Belk 2015).

We note that the aforementioned three solutions to the subaltern quandary focus on only some isolated elements of the marketing system as defined by the MAS framework. While $\mathrm{BoP}$ assumes a paternalistic approach (from the vantage point of powerful actors in action fields) calling for a minimalist tweak in the system's outcome through the inclusion of the subaltern into the list of passive value receivers (element 3), the moral economy approach in contrast stresses the supremacy of nonmarket social mechanisms over market-driven ones in provisioning community needs (element 1 ). The capabilities approach re-focuses the discussion toward the enablement of a wide range of essential 'beings' and 'doings' (e.g. health, hygiene) which lead to effective 'functioning' in action fields (element 2).

To integrate these various frameworks, we draw on the concept of dignity. The archaic meaning of the concept signifies high social status within a specific social order and the normative expectation (by the elites) to be treated in accordance with elevated status (Rosen 2012). In a reversal of the orthodox meaning, the broader interpretation of dignity denotes the absolute worth of human beings (Adler 1967; Egonsson 2012; Kant (2002) [1785]; Nussbaum 2011). While the concept's religious interpretation is linked to the special status of human beings as God's vicegerent on Earth, the standard principle of dignity declares that human beings deserve extreme respect and reverence by virtue of simply being 'human' (Egonsson 2012). Rosen (2012) distinguished four meanings of the broadened concept: dignity as status, dignity as behavior, dignity as inherent value, and dignity as respect. The Universal Declaration of Human Rights stresses its first meaning thereby positing in Article 1 that "all human beings are born free and equal in dignity and rights" and thus eschewing the various assumptions of intrinsic status differences. Its second meaning denotes that dignity arises occasionally, due to people behaving in dignified ways, especially, when they stoically resist their intrinsic negative inclinations (Schiller 2005). The third meaning is based on Kant ((2002) [1785]), who proposed that humans, due to their being the source of the moral law, harbor unconditional worth (i.e. dignity) which is beyond the valuation of any kind including that of markets. The final meaning, which we use as a guiding definition in this investigation, is based on the view that it is a human duty to respect the dignity of humanity, and that failure to do so would result in undermining one's own humanity (Rosen 2012). Dignity is compromised when people's humanity is denied, even more so if they are prevented from behaving in dignified ways.

\section{Method}

\section{Research Context}

With the theoretical underpinnings discussed in the previous section in mind, we initiate a qualitative inquiry to investigate 
how subaltern consumers understand and interpret markets, marketing systems, and the impact of marketing systems on their lives. This investigation is undertaken in the Mirzapur district of the Uttar Pradesh province in the Ganga belt of India. This region is also known as Purvanchal, the eastern region. The district is arguably one of the most underdeveloped regions of India with the population of around 2.49 million, over 70\% of which is the rural population. Agriculture is the mainstay for livelihood in this district that in fact represents the overall trend in India. The district has the literacy level of $68.47 \%$ with female literacy reaching $56.85 \%$, which are well below the national average. The average income per capita in Mirzapur was INR 11,408 (USD 171.59) in 2009-2010, which is considerably lower than the provincial per capita income of INR 16,390 (USD 246.52). People in this district speak Bhojpuri, Awadhi and Bagheli dialects of the national administrative language Hindi.

Mirzapur also hosts India's carpet-making industry. There have been some reported incidences related to bonded labor (debt slavery) (Srivastava 2005). It has a high proportion of distress migration of unskilled and semi-skilled workforce to the western part of the country, particularly Mumbai, the financial capital of the country (Mishra 2012). Some parts of the region have also been affected by the extreme left-wing armed rebellion, called a Naxal movement in India (Ministry of Home Affairs, Government of India 2016).

\section{Inquiry Approach}

Maintaining that general epistemological consideration determine the choice of a method (Schwandt 1994), in this inquiry, we follow the constructivist orientation. Constructivism is a research paradigm that questions the existence of a single objective reality. The perspective is based on the precept that "realities are social constructions of the mind and that there exist as many such constructions as there are individuals (although clearly many constructions will be shared" (Guba and Lincoln 1989, p. 43). To inform our understanding of marketing systems (the etic perspective), we explored how research subjects constructed local, folk, internalized interpretations of marketing systems and themselves acting within these marketing systems (i.e. the emic perspective). People face complex marketing phenomena and apply mental heuristics and analytical patterns to understand what their lifeworld reality is. In doing so, they find themselves to be in the process of interpreting markets-related complexity. In these processes, their consciousness tends to engage the complexity (such directedness of thought is referred to as intentionality) by distinguishing the order out of chaos. Hence, it would be less tenable from the constructivist perspective to assume that these local, fragmental, at times rudimental and "thin layers" views would indicate the true nature of the marketing system under focus (Peñaloza and Venkatesh 2006).

This inquiry makes use of a holistic design embedded with multiple philosophical perspectives to accommodate for account variations across individual cases. We used intensive interviewing as the main data collection instrument. We studied, analyzed, and juxtaposed twenty personal accounts in detail to disentangle localized constructions. The interviews were fully transcribed verbatim (Poland 2002), and then translated from the local language (Bhojpuri, the distinct dialect of Hindi) into English. While going through the transcripts in an iterative manner, we found that many contextual nuances tend to fade in the translations. Therefore, we applied codes in the local language wherever possible. As the need for triangulation arises from the ethical need to assure the validity of the processes (Tellis 1997), we decided to focus on investigator triangulation (Denzin 1984), whereby three authors examined each other's interpretations to establish truthfulness. Besides, trustworthiness was assured through prolonged engagement, persistent observations, peer debriefing, thick description and purposive sampling (Erlandson et al. 1993).

\section{Data Collection and Analysis}

The qualitative material has been collected by the authors in the Chhanbey block of the Mirzapur district. One of the authors stayed in the region for 1.5 years, where he worked as a development practitioner with the National Rural Livelihoods Mission (NRLM), which is the poverty alleviation program of Indian Government. NRLM aims to achieve its objective of poverty alleviation through developing strong grassroots institutions of the poor. In all, 20 in-depth interviews were conducted. Out of these, three interviews were conducted with a group of women, who were from the neighboring province of Bihar and came to the training session of the Self-Help Group, an informal group of women (Figure 1). The interviews were conducted over a span of nine months.

The duration of a typical interview ranged from 40 minutes to 100 minutes. The follow-up and repeat interviews were conducted with many respondents to decipher contextual nuances in their narratives. The interviews conducted were semistructured. It was ensured that respondents felt comfortable while narrating their opinions. The semi-structured interview design enabled an interviewer's control over a highly unpredictable interviewing process as well as flexibility required to delve deeper into relevant issues. While selecting respondents, it was ensured that they represent disadvantaged consumer groups including women, low caste members, and minority religion consumers. Along with the above, their willingness to talk to the interviewer along with an ability to narrate effectively were set as criteria for selecting respondents. Here, the experience of a co-author staying in the region played a great role. All respondents were thoroughly briefed about the purpose of the inquiry. Their consent has been duly solicited before participation. (Table 1)

We carried out a thematic analysis, which is a method that is essentially independent of epistemology and can be applied across a range of epistemological approaches (Braun and Clarke 2006). Using this method, we identified general patterns (themes) pertaining to the milieu under focus. A number of 


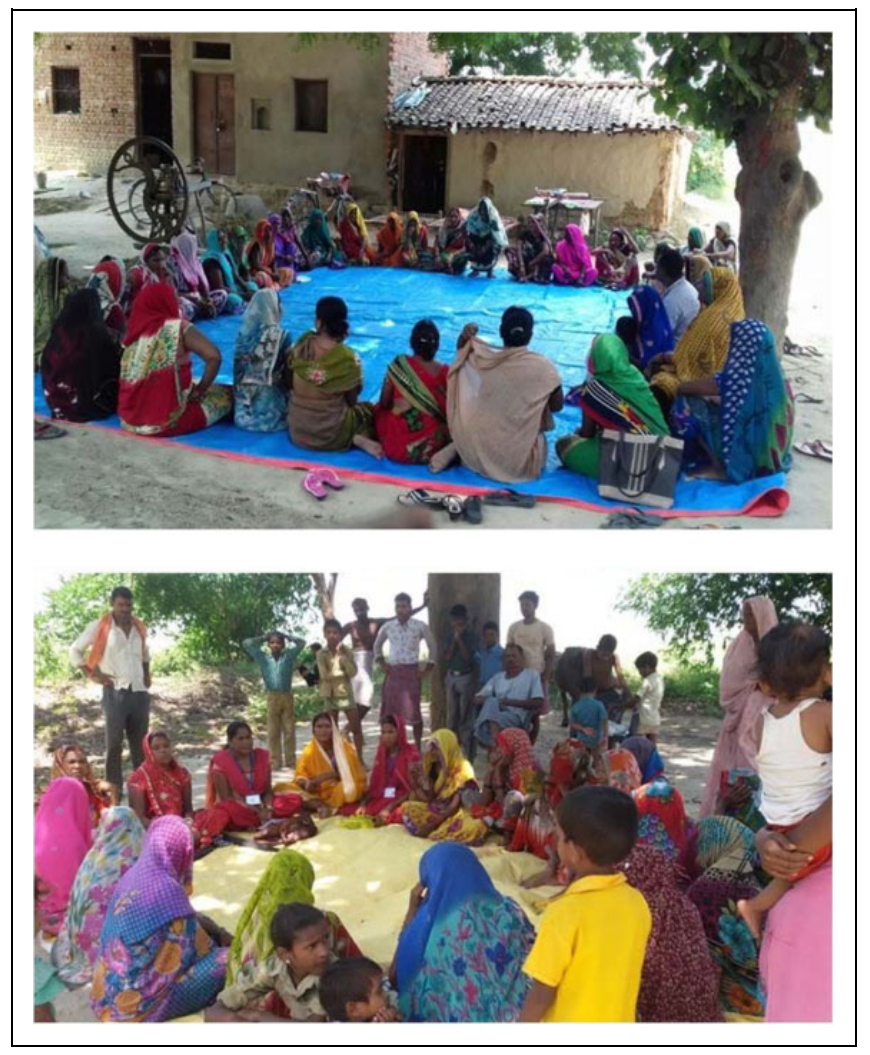

Figure I. Villagers from the lower castes congregate for the self-help group meetings.

themes emerged through our iterative reading and re-reading of the transcripts (Rice and Ezzy 1999). The analysis started immediately after the first interview and continued until we reached the point of theoretical saturation. We kept notes of reflections while reading the transcripts and then later compared them to assure consistency in our interpretations. We used last four interviews to validate and enrich emerging themes. In most of the cases, we followed up the interviews by conducting informal discussions with respondents in informal settings to better understand the nuances of their narratives. These informal discussions were not recorded and transcribed; however, they helped us to the great extent to interpret the material.

\section{Interpretation}

\section{Marketing Systems, Problematization of Dignity, and System Building Capabilities}

In this section of the article, we present the results of our interpretation. While reading the informants' narratives, three main questions have become prominent in furthering our understanding: 1) How do potential market system actors become subaltern? 2) How and why subaltern dignity experiences arise in the context of market relations?; and 3) How is dignity experienced and problematized by subalterns within marketing systems?

\section{Orthodox Dignification, Differential Endowments, and the Impact of Neoliberal Marketization}

Dignity has always been a part of hegemonic discourses in India. The archaic concept of dignity, i.e. respect for high status, was thoroughly imbued in the caste system and the socio-cultural traces of the Jajmani order. Dignification was reserved for the purity and the "pure" forms of labor attributed to higher castes (Dumont 1970), which also entailed higher castes' total control over the emergence and growth of orthodox market systems (e.g. economic activity, entrepreneurship, ownership, income-generating work, trading, barter exchanges, distribution, currency) (see Vikas, Varman, and Belk 2015). Viewed through the MAS prism, such restricted dignification was a social mechanism that defined how individual endowments were assessed, integrated, and used for value generation. Although the system greatly favored higher castes while both limiting and undervaluing the input of lower castes, in general, it offered a minimal degree of social security to subalterns (e.g. protection from hunger).

The orthodox system offered relative stability within action fields as the roles and acts were meticulously predefined. In principle, although the "symbolic veil of honor" presented higher castes as selfless caretakers of the order (Vikas, Varman, and Belk 2015), it appears self-interestedness had for centuries corrupted the purportedly idyllic structure of the Orthodox system. The elites found themselves not only in the business of defining what needs were and how these needs were to be provisioned but also in the business of shaping rules and regulations which guaranteed a steady flow of different types of capital into the elite "coffers".

"I mean others, like Thakurs and Brahmins, had a lot of agricultural lands. They would make people slaves. "You stay at our place, take care of land and cows, and you will get food, but we would not give money!" Stay there day and night, for 24 hours do their slavery and they would only give food, this will be slavery. One could not go anywhere, one had to work bonded. Now there is no boy who wants to be bonded. Previously we used to stay there, but if they now call us I do not go. I will not go, I will work in whoever's farm I wish. There cannot be any stopping in that. A tradition is also going for long - this is a small hamlet, and the villagers of Dewri on the other side of the road were goons from the beginning. They would keep us bonded, they would keep us tied. Now, slowly things have changed and nobody goes there now, nobody does their slavery, nor do they shepherd their cows and buffaloes, everyone goes their own way. I will work wherever I wish, earn and eat. I will not be anyone's slave, I will work independently." (Sushil, the Chamar caste)

The quote attests to the change in the viewpoint whereby the rise of marketization rips apart the veil of honor. For a young low caste member, orthodox dignification that ensured stability in action fields for centuries is not meaningful anymore. Now, working in farms for food only is redefined as "slavery" and people who do that are seen as "goons". For Sushil, the 
Table I. Profile of Informants.

\begin{tabular}{lllllll}
\hline$\#$ & Name & Gender & Religion & Caste & Age & Profession \\
\hline I & Sudama Singh & Male & Hindu & Kurmi (OBC) & 27 & Agriculture /small shop \\
2 & Mita Devi & Female & Hindu & Chamar (SC) & 33 & Agricultural labourer \\
3 & Minal Devi & Female & Hindu & Kol (ST) & 28 & Community mobilizer \\
4 & Sushil Kumar & Male & Hindu & Chamar (SC) & 20 & Student \\
5 & Lakhan Pyari & Female & Hindu & Sonkar (SC) & 30 & Agricultural labourer \\
6 & Preeti Yadav & Female & Hindu & Yadav (OBC) & 50 & Agriculture/animal husbandry \\
7 & Dinkar Yadav & Male & Hindu & Yadav (OBC) & 55 & Agriculture/small shop \\
8 & Kaleva Devi & Female & Hindu & Lohar (OBC) & 24 & Community mobilizer \\
9 & Sita Devi & Female & Hindu & Nishaad (SC) & 20 & Community mobilizer \\
10 & Murad Ansari & Male & Muslim & OBC & 30 & Poultry farmer \\
11 & Kamla Devi & Female & Hindu & Chamar (SC) & 35 & Agricultural labourer \\
12 & Ravi Kumar & Male & Hindu & Nishaad (SC) & 38 & Shopkeeper \\
13 & Shah Bano & Female & Muslim & OBC & 35 & Tailor \\
14 & Mushtaq Ali & Male & Muslim & OBC & 37 & Shopkeeper \\
15 & Aruna Devi & Female & Hindu & Chamar (SC) & 25 & Agricultural labourer \\
16 & Komal Devi & Female & Hindu & Chamar (SC) & 30 & Agricultural labourer \\
17 & Phool Kumari & Female & Hindu & Kurmi (OBC) & 40 & Community mobilizer \\
18 & Hemlata Devi & Female & Hindu & Paswan (SC) & 55 & Community mobilizer \\
19 & Belpatti Devi & Female & Hindu & Chamar (SC) & 40 & Community mobilizer \\
20 & Anchal Kumari & Female & Hindu & Khuswaha (SC) & 22 & Agricultural labourer \\
\hline
\end{tabular}

capability to choose, i.e. independence, autonomy, and freedom, is a new hallmark of his dignity.

The newfound resource is a double-edged sword for many subalterns. Our respondents emphasize "working outside". They migrate to industrialized parts of the country in the hope of capitalizing on new opportunities afforded by developing markets. However, some of them are unable to quickly adapt to the new reality and thus fail to secure decent paying jobs. For example, for Mita Devi, a well-paying job is simply an unattainable dream. She is a 33 years old lady from a landless family of the Chamar caste (traditional cobblers but considered one of the lowest 'untouchables' in the Hindu caste hierarchy). Married at age of 14, Mita struggled to complete her basic level school education. Currently, she is trying hard to get a job in a state-owned railways company. Another landless female laments the lack of appropriate market-participation skills:

\footnotetext{
"I also think that [proper education, skills] I do not have today, but maybe tomorrow my children would grow up and earn. Then maybe our needs may be met, we also might get to live good and happy life.... Our life is gone, but our children's life should be better when they earn. Due to this, we think that even if don't eat one time we would educate our children." (Kamla Devi, Chamar)
}

The desired education provides proper skills, but it has to be through specialized (e.g. a private, English language medium) schools that are usually beyond subalterns' financial capability. Most respondents view state-run schools less positively and doubt their ability to provide the right education. Hence, Mita and Kamla's cases indicate that both lack of schooling and dysfunctional schooling may contribute to the subalternity. Nevertheless, simply having right skills may not be sufficient either. Sudama Singh, a 27 years old young man from the
Kurmi caste (OBC) who currently runs a paan (betel leaf) shop in his village, was confident in his skills. He used to work as a security guard, chaukidaar, in a sprawling residential society (i.e. gated community) in the urban center of Gurgaon, Delhi. His future seemed bright as he expected promotion and extra commissions. To his dismay, he had to return to his village as Brahmin "friends" working with him at the same place incited others against him which could have potentially turned into physical violence. This was due to him refusing to do upper caste "slavery".

\begin{abstract}
"I went with Brahmins, people from a different caste. For 7 years, I cooked food for them two times a day, you understand ... Then, the Brahmins from D (a village nearby) working there conspired against me and I had to return home, and thereafter I have stayed at home... Thus, I had to run from there and thereafter I have stayed here ... they said that this guy should not stay here. Many people came to attack me... I somehow spent the night, settled accounts the next morning and came back home. Caste discrimination is there. The higher caste people (e.g. Brahmins) always detest the lower caste people, and think that this [lower caste] person is a servant, and so, and it [this situation] demands great caution. There, one must, every time, become others' slave. And one cannot ward off this slavery, if they say something, this must be done. Only then the job can be kept, else it cannot be done." (Sudama Singh, Kurmi)
\end{abstract}

It appears that Sudama became a willing participant in this caste-based custom at first, while increasingly becoming aware of its problematic nature. He wonders about the metamorphosis of the caste system which transformed from an overt system into a covert practice embedded in a supposedly free working environment. Nonetheless, a working family member may not be a guarantee against misery. The husband of Komal Devi is 
one of those lucky people who has a decent job working as a carpenter in Mumbai (2000 km away from the village). However, he now visits his family and children only once a year. Since he left, his remittance gradually declined to cause a big distress for his family, while Komal has yet to visit Mumbai since they have got married 14 years ago. This appears to be another path towards subalternization.

Out of the people interviewed, Lakhan Pyari, a 30-year-old lady of the Sonkar caste (traditionally pig rearers; also considered as untouchable) is more or less "lucky" as she now owns a pucca (permanent) house. She had briefly lived in Mumbai where her father worked as a driver before getting married to a person from the current village in the Mirzapur district. Her family (including her husband, four daughters and two sons) is landless, while her husband sells vegetables on a cart in the nearby town and she occasionally works as a casual laborer in an agricultural farm. As she explains, they cannot afford to send children to school, while frequent bouts of diarrhea in the village causes unplanned expense shocks. More importantly, their subaltern situation is driven by the costly debt (approximately $60 \%$ interest paid annually), which is the result of predatory lending practiced by the Thakur-Brahmins of an adjoining village. Lakhan says that they face frequent intimidation (both physical and social) from the lending party who use their dominant social status.

Shah Bano, Mushtaq Ali, and their three children are a family from the Muslim minority. They have put their trust solely on market for their livelihood but it failed them. Shah Bano is well versed in tailoring, sews clothes and also trains other village women (predominantly non-Muslim). Mushtaq used to own a TV repair shop, however, he was forced to close the shop multiple times because of evictions enforced by higher caste landlords. Now, he is unemployed and trying to set up a cosmetics/bangles shop. The family currently survives due to the consistent help of a Hindu friend Mahesh.

Summary. The aforementioned cases indicate that the modern form of subalternity arises at the junction of the orthodox system and the process of marketization. Many subalterns find themselves between a rock and a hard place, that is, orthodox market practices and new free-market realities. Marketization destabilizes orthodox structures and action fields thus freeing labor from its orthodox bonds on a mass scale (Polanyi (2001) [1944]), however, new dependencies and vulnerabilities are recast in the process. Although neoliberal marketization allows subalterns to problematize traditional market relations, it falls short of offering a radically different system of provisioning. What is problematic is marketization upsets orthodox dignification which guarantees survival, while in turn failing to offer viable provisioning solutions for impoverished masses.

\section{Problematization of Dignity through Experiencing Apophatic Dignity}

Our reading of interviews indicates that subalternity is purposefully effected by both subalterns and powerful market agents as an indispensable element of newly emerging market relations. Purposeful effectuation (Sarasvathy 2001), i.e. constructing and sustaining a meaningful marketing system structure, can take many forms. In the respondents' phenomenological world, its impact is experienced as apophatic dignity. Apophatic experience arises when people perceive a phenomenon by virtue of what it is not (or should not be). By describing incidences related to the personally experienced problem with human worth, the respondents indicate what is structurally absent, and hence, desirable in marketing systems. By doing this, they problematize the way the whole market system structure is constructed. We observe the following dimensions of apophatic dignity: symbolic anchoring, dedignifying instrumentalization, and dehumanizing practices.

Symbolic Anchoring. Newfound market wealth combined with caste dynamics has given rise to extreme consumption conspicuousness in India, especially in rural areas (Vikas, Varman, and Belk 2015). Consequently, success in life in gauged via the things people own.

\footnotetext{
"The signs of good living would be these - there should be a good car so that if we have to travel somewhere we don't get baked in sun; there should be a beautiful house in which all my family can stay comfortably... our life should be such that people recognize us as something when they see us." (Mita Devi, Chamar)
}

Mita's wish is that her family ceases being seen as "nothing", that is the threshold they must traverse beyond. In this context, it is recognized that the subaltern situation, the harsh reality of deprivation, has become a symbolic anchor (i.e. a dynamic gauge) for market prosperity. "Nothingness" needs to be overcome.

"However, so much is not happening as the situation is bad. From my 'Ajeevika work' I get Rs 1000 (US\$15) every month, otherwise, my husband has no work. So, the situation is bad now, but we think that maybe it would improve in future -we get to have good house, own shop. Good life everyone thinks that one has a good house. One gets to eat in comfort, and children also stay well, they study and move ahead, what better than that!" (Shah Bano, Muslim)

The misery of Bano-Ali's family, which is measured at $\$ 0.10$ per day per person, is extreme. We must note that the official standard of poverty that is $\$ 2$ per day would be deemed a luxurious life for this family. Moving beyond "nothingness" is not just an incremental increase in income, rather it represents a symbolic shift that reflects the hope of escaping excruciating vagaries of life at the edge of survival. Within society at large, the subalterns are the group against which wellbeing judgments are made. The problem is that the relativistic market happiness perceptions of the members of society depend on such socioeconomic comparisons. For instance, while contemplating on his lack of ownership of a personal means of transport, a respondent makes the following observation:

"On road someone is going by scooter, somebody is going be Apache, Pulsar [the brands of expensive sports bikes in India]; 
four-wheelers are running, some with small tires some with big tires, but are not they [rich people] man too? Do they have 3 hands and legs? What has he done [to deserve] so that he is traveling in such a big vehicle? What is their work? For how much time are they working? Sir, I think of these things. They are humans too, they too have 2 hands and 2 legs, but how are they moving around and how our villagers are moving around in bicycles, they do not even have motorcycles, even though they work the same [hours]." (Sushil Kumar, Chamar)

As subalterns realize their dire condition through such market assortment based comparisons, the similar comparisons are made by other people to realize that they are relatively happier. What is problematic is that the subaltern group reacts to this reality by coming to terms with such rationalization and thus contributing to the (re)construction of the very system structure they find problematic. Mita Devi exclaims in despair "... today we accept that we are poor".

"Even if I have Rs 10-20 I am happy. I think that I have Rs 10-20, but some may not have even that much and somebody has Rs one lakh. Whatever God has given me I am content, and I will work in that much, I will not take from anyone." (Mita Devi, Chamar)

"Only future would tell, what can I tell? If God wishes it may happen, and he if he does not wish it may not happen. We might think a lakh times that we would become rich, but that would not happen. . . . When I don't have so much, I have to stay content with whatever I have.” (Lakhan Pyari, Sonkar)

These rationalizations illustrate the acceptance, perhaps unconsciously, of the symbolic anchor role within action fields, thus accepting the burden of becoming an instrument of market happiness (even if it is minuscule in comparison to Western countries) for the rest of the population. Although it is a dignified way of accepting an important function within the system, harsh living conditions would still require a degree of contentment. Researchers attribute the observed condition of compromising with societal injustice to 'adaptive preferences' (Sen 1985). Adaptive preferences theory refers to the mental state of people when they become unable to offer a realistic assessment of the own situation. A vulnerable group not only stops expecting any help from anyone but also ends up feeling content with morally wrong societal practices, including own subjugation and humiliation. Subalterns start attributing the new normality of disrespect for human worth to own grim situation. The only escape is assumed to be via increased participation in problematic processes of the same marketing system, which leads to further reinforcement of the similar practices. As symbolic anchoring is a structural phenomenon, its constant recurrence means that escape from the grips of subalternity for a member of society will be equally met by a creation or relegation to this status for other members.

De-dignifying instrumentalization. Instrumentalization occurs when people are used as means rather than ends (Kant (2002) [1785]; Laczniak and Murphy 2006). The social norms of using the other as a means of attaining market happiness are evident in symbolic anchoring practices as discussed earlier. As Orthodox dignification gave way to market-based dignification, the construction of subalternity has become even more purposeful. Previous research also shows that privileged groups, facing the pressures of marketization, become vicious in hindering exchange and re-configuring value systems to recast their superiority (Vikas, Varman, and Belk 2015). We find that, for example, physical violence is still common.

"if I go somewhere else, they [land owners] will use force... If I refuse they will fight, beat. [They would say] your father is working in my farm why would not you?!... [No!] I will earn by working somewhere else." (Sushil Kumar, Chamar)

This commentary demonstrates that in the current marketing system the actors imbued with disproportionate market power attempt to effectuate (Sarasvathy 2001), i.e. create, the powerless to be used as a mere tool to be exploited. Expressing the need for a new job that would respect his ability to reason, Sushil finds it frustrating that distorted market arrangements that instrumentalize individuals could still exist. The subaltern group is forced to stay close to large farming enterprises and offer their labor in return for minimal pay. The neo-liberal policies discussed earlier have had an impact on everyone, including land owners. In contrast to the subaltern group, the land owners have the market power to act flexibly, so they try to externalize costs and pass them on to laborers. Another case in point, Shah Bano's husband Mushtaq Ali tells about how he used to run a successful TV repair shop. However, it had to be shut following frequent evictions by the upper caste landlords wherever he went. Shah and Mushtaq presently run a small cosmetic/bangles shop that itself is facing the same danger of relocation. The problematic nature of these occurrences is that they lead to perpetual subalternity and ensure that a part of the population always remains in the dire condition.

Instrumentalization is not always tangible, it can also be symbolic. Kumar tells a story of how he managed to buy an expensive shirt to impress his relatives, friends and other villagers. Perhaps, he wanted to use it as a counter-weight in the game of market dignification based on conspicuousness. However, this was not appreciated by the wealthy people in the village who associate themselves with higher castes. They expressed their doubts about if he could really afford such product hinting that it might be stolen. Hence, the consumption of venerable market outputs may not be helpful, as it is considered socially un-befitting if done by subalterns. This point challenges the key BoP assumption that market artifacts can make a significant difference. Rather, symbolic instrumentalization ensures that the elitism of higher castes is reinforced and maintained. It appears that the logic of free market applies to the elites only, while the subaltern group is excluded whenever possible (Varman, Skalen, and Belk 2012).

Instrumentalization is not always a "powerful versus powerless" phenomenon. In fact, it becomes reinforced among 
subalterns themselves as well when the logic of marketization fuses into everyday social practices and becomes a way of life.

"Also, even if one tries to earn himself through some means then there are various social ills in the village like caste discrimination, jealousy among relatives and friends. They will feel insecure and try to create obstacles so that one cannot develop." (Sudama Singh, Kurmi)

Most respondents dream of 'good old times' when communities were operating as tight collectives based on wellestablished reciprocal systems. It is difficult to ascertain whether such impressions are true, however, many now complain that genuine interpersonal reciprocation has drastically reduced. It appears that instrumentalization has spilled over to everyday lives of subalterns. The respondents note that it has become normal for many to use others, including their extended families (note that the people living in the same locality are likely to be connected by kinship), as a means for their individualistic ends.

Dehumanizing practices. Dehumanizing tendencies occur when people "perceive of or treat someone as less human, not fully human, or subhuman" (Oliver 2011, p. 87). We observe that new market-based dignification leads to tendencies through which subalterns are seen as human beings who deserve less or no respect.

"People despise the villagers who are growing poor. They think that they have become smaller, and worthless... People will stop giving them invitations; even they won't like talking to them and probably also stop that... Only those who have something from their hard work - have food and shelter is recognized by other people, otherwise nobody will recognize. Even if one starves, one will have to stay hungry and nobody will help." (Sushil Kumar, Chamar)

Sushil complains about little compassion among people, specifically, towards people who find themselves in destitute situations. While the free market ideology agitates the examples of "market heroes" who became newly rich, the public opinion of the poor, in contrast, tends to lean towards negative archetypes. The feelings of worthlessness and 'shrinking' emphasized by Sushil highlight the symbolic dimension of "being" within marketing systems. As we argued earlier through illustrating symbolic anchoring and instrumentalization, subalterns may be precluded from effecting market exchanges, however, they are still an integral part of the total marketing system through performing specific functions within action fields. Hence, subalterns use the concept 'shrink' to indicate the loss of human dignity, and thus their control over life circumstances.

Within action fields, dehumanizing also occurs when some market actors label and treat another group as though they are incapable of independently making rational market decisions.
"In the market, it often happens so that if you go to a big shop the shopkeeper does not understand who is of higher caste and who is of lower caste. He assumes that we are of lower caste. What happens in that is if we ask for good clothes he thinks that they would not be able to pay. Repeatedly he would bring out the stuff that one does not want to buy. Then one is forced to buy what one does not want. This also happens. At times it happens that we think while going that we would tell them to show good ones. Later they say that "Yes, yes we would show good ones, but you won't be able to buy those. You go!" . . they identify us from our ways and clothes. At times in some shops, they utter such words that one does not feel like going to market." (Sita Devi, Nishaad)

Sita would like to stress her right to be able to access all choices in the market without inhibition. She wonders if some marketers are in the state of self-imposed denial that subaltern consumers are capable of making right purchase decisions. Stereotyping biases restrict the ideally free and fair movement of consumers in the marketplace. The informants mention that the choice they are offered in some shops is either substandard or limited. Such elitism has a societal cost - it is based on dehumanizing the lower castes and denying them access to market assortments. The informants also talk about some market assortments that are used to discriminate and dehumanize people. The narratives indicate that the elites use certain assortments not to satisfy the demand but to satisfy their own elitism, and hence by implication, the need for dehumanizing.

"Shops are mostly owned by Brahmins (highest in the social hierarchy). Sometimes, it may happen that if Brahmins wish then they will give, else we will have to keep standing and pleading. At times if we send our children, they will discriminate and send them back, even when we are paying money." (Mita Devi, Chamar)

A respondent who had faced the wrath of upper caste on multiple occasions recalls:

"I was badly thrashed by a Thakur (a high caste person) from an adjoining village when I asked for a meager one INR due to me after he had taken a paan (betel leaf) from my shop." (Dinkar Yadav, Yadav)

The accounts above are the examples of another dimension of dehumanization: humiliation in public spaces. The accounts indicate that humiliation happens irrespective of the subaltern group acting as the buyer or the seller. In the first case, the subaltern group is blatantly denied access to products/services that are otherwise available for exchange, whereas in the second case the dominant group simply denies that the exchange has occurred. Humiliating experiences lead to the dispossession of significant resources by the subaltern group.

Summary. Although subaltern participation in the market system is limited, the group's symbolic participation in marketing systems is considerable. As Orthodox dignification seamlessly became co-opted as a new market-based dignification, which affords respect to the wealthy while inspiring antipathy towards 
the poor, subalternity has taken a new turn. Subalternity as a phenomenon has become a purposefully effectuated element of the dominant marketing systems' structure (Sarasvathy 2001). Subalternity in most cases serves the function of a "control group" as flawed marketing structures take this group's status as a reference and "feed" it on the receiving end of the processes of symbolic anchoring, instrumentalization, and dehumanization. The processes reverberate in subaltern experiences and reveal that the fusion of archaic social and modern market mechanisms ensure that subalternity remains and grows. In this context, market and non-market forces do not counter-react as assumed by the moral economy approach (Polanyi (2001) [1944]), rather they form an interpenetrating unity that gives rise to flawed marketing system structures. Both market assortments (the BoP's focus) and social mechanisms (the moral economy's focus) have a potential to undermine dignity, thus cannot be taken as default solutions.

\section{Enhancing Dignity via Minimizing Dissimilitude}

Our interpretation of the narratives shows that minimizing dissimilitude is the main concern for subalterns dreaming of equal participation in markets. For them, dignity means indistinguishability, that is, becoming similar to everyone else. The themes that support this interpretation are as follows: aligning for ordinary livability and market as indistinction-scape.

Aligning for ordinary livability. The informants highlight ordinary consumption outcomes as means of attaining respect in society. These outcomes can be understood as functionings (i.e. beings and doings) that are perceived to be important for attaining respectful life (Sen 1999). Such functionings include being free of food insecurity and chronic hanger, being in ownership of private consumption items such as adequate clothing or a private means of transport, as well as more fundamental solutions like owning a pucca house, being able to educate children in a well-functioning school, being able to access adequate health facilities, and being able to hold a secure government job.

"Good life is when one does respectful work, children study well, move forward and we too feel good in moving forward... [Good life is when] a good house gets built for us - [but now] we are in so much trouble. This [would happen when] life moves well, what else! I could not study much, but my children should get to study. After studying they get some job and do it. Their life should run better. We have gone through so many troubles but they should not face them." (Shah Bano, Muslim)

Shah Bano goes further stressing the importance of reclaiming their fame, which in this context simply means being able to own a valuable property or even getting the children educated, the result of which can only be experienced in distant future. Thus, fame or respect in this context means ending the restrictiveness of destitution and the pain of deprivation. In general, our respondents are primarily concerned with ordinary but fundamental circumstances of life such as personal hygiene,

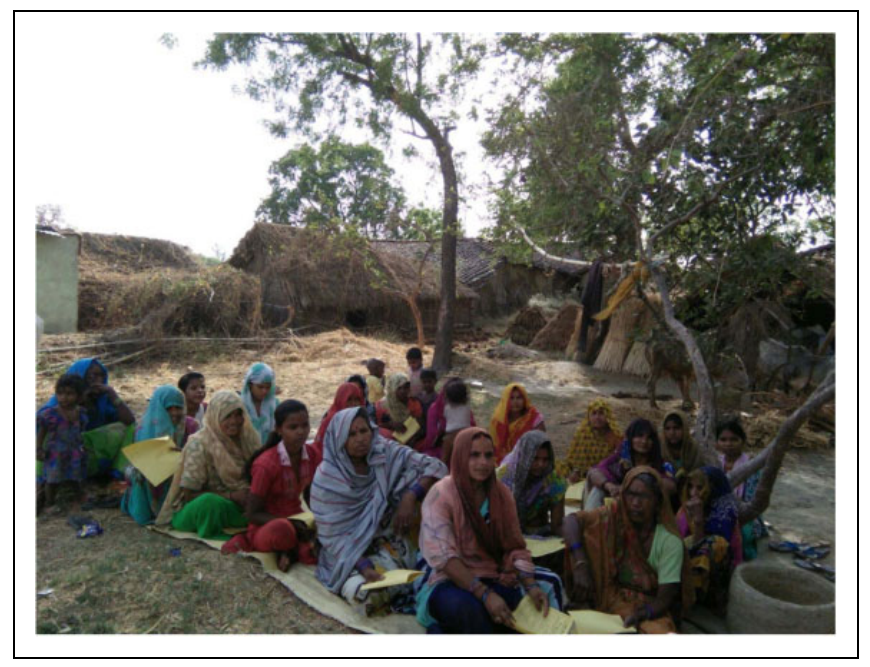

Figure 2. Subaltern women and their substandard housing (in the backdrop).

cleanliness, personal space, privacy, nutrition, clean water, waste disposal, temperature control which are essential for not falling under the minimum threshold of bearable human existence. The primary problem subalterns are concerned with is the lack of capabilities to attain basic indispensable provisioning outcomes (mostly taken for granted in Western countries). It appears that what they yearn for is the capability to restore human dignity, which in this context means the bare minimum of livability. We note that notions such as distinctiveness, recognition, personal achievement, self-fulfillment, or enriching experience are absent from the discourse. (Figure 2).

We also find that for most informants simply ending chronic hunger is another concern of dignity. Recurrent feelings of hunger bring about the humiliation that is not always apparent.

"I think that in future we do such things that in one village our name spreads. They say that, "[Look] how she was and what has she become now!" Say, even if there is no cloth at home but there is a marriage [party] then we borrow and buy good clothes. Nobody would come to our homes to see whether we have eaten or not, but when we go out the clothes would be the thing visible. They would say that these people are well." (Sita Devi, Nishaad)

Reaffirming the lack of hunger as a conventional norm of dignity, Sita explains how they make attempts to mask their dire situation by exhibiting the faked capability of affording new clothes for specific occasions. Traditionally, appearing in the same attire in public for different occasions is highly stigmatized as the hallmark of poverty. Hence, there is an ongoing struggle to trade-off publicly observed versus unobservable functionings. Faking various capabilities is common among subalterns. In a few occasions, some of our informants boasted about big sums of money they spent to throw a large marriage party or to renovate their house. According to what we knew about their circumstances, these numbers sounded unrealistic. 
"People do not go to houses to check whatever they are eating. They see the clothes of the children. They would not see your food or your money. If your children are wearing torn clothes they would say, "They have so many children and they cannot even afford clothes!" Due to that, our status decreases. If there is money, there is status, otherwise, there is no respect. Previously, there would be respect even without money, but in this age when there is money, there is no respect without money." (Lakhan Pyari, Sonkar)

Lakhan shares her technique of manipulating symbolic cues to influence others' wealth judgments of her family. We believe that by doing this, subalterns make episodic attempts to flee their perceived status occupancy. They detest being distinctly identified as belonging to a group of utter poor households. There is a constant attempt, both tangibly and symbolically, to appear as someone who can potentially surmount the dedignifying status of the lowest social class, as it is perceived by others. In doing this, they wish to "disappear" in the crowd of ordinariness, that is simple humanity, rather being treated as a specific segment.

Market as indistinction-scape. Market experiences of the subaltern group are radically different to those of the privileged. As the cases of apophatic dignity demonstrate, our informants feel that they are problematically categorized as "less-thanhuman". In most of the narratives, we came across a normalized, yet slightly noticeable discursive distinction of 'they' versus 'us'. For the subaltern group, 'they' represent all others from their immediate surroundings who are judged to have adequate life conditions. As language represents the rituals of recognition (Kuch 2011), this practice reveals the nature of subaltern experiences: the hope to join the ranks of "they". Hence, subalterns dream of a spatiotemporal dimension where divisive distinctioning and related humiliation does not exist.

"Market is what is called 'Bazaar'. If you go there [as a free person] everything is available, be it food, clothes or drinks, everything is available. According to me, that is a market.From small to big things are available [with no restrictions], that will be called market. [The place] where from Re 1 to Rs 10000 to Rs 10 lakh worth of goods are available is called market." (Belpatti Devi, Chamar)

"Going to market is always a liberating (free) thing... I can enter any shop without inhibition which I cannot do $\mathrm{i}^{1} \mathrm{n}$ a village as I am from a lower caste and a female. Here [in a regional bazaar] shopkeeper gives me choice to choose the things which were not possible in a small shop in my locality." (Lakhan Pyari, Sonkar)

Belpatti and Lakhan see 'bazaar' as a utopian space where the provisioning of essential needs happens with no impact on their capability of exercising their free will. They construct this notion idealistically as the space that allows them to escape, albeit momentarily, the difficulties of life, and hence, their undignified lived-in reality. The market is constructed as the "garden of Eden" where most needs are met, specifically the symbolic need to freely exercise own autonomy by being able to easily access various choices. For them, it is an exciting place where people socialize freely and their actions are not inhibited by status/caste delusions.

"I always feel like going to bazaar since my childhood. My caste status is concealed there and people do not probe that. Though shopkeepers know/understand that by years of association, many shopkeepers hardly bother about that ... for them, their business is important than our caste." (Sushil Kumar, Chamar)

Sushil is excited about the possibility of transcending the orthodox boundaries of dignification via immersing in the market. In his view, the market allows him to become indistinct from the rest of the population, and thus become equal and free. However, it may not be as straightforward as it seems, since problematic symbolism lingers post-purchase. For instance, an informant indicated that he wished to challenge perceived status differences by purchasing and wearing an expensive shirt. However, in congruence with similar instances observed by Vikas, Varman, and Belk (2015), this kind of consumption episode turned into further humiliation as people doubted the informant's ability to afford the good while hinting that it might have been stolen or borrowed. In their focus on orthodox patterns and the desirability of new market relations, what subalterns may fail to realize is that market forces are not as neutral as it is assumed. Local symbolism gets imbued in market structure (Kadirov and Varey 2011).

\footnotetext{
"Marketing is English word by which people mean that they buy whatever they need. In Hindi, they will say let us go to bazaar... There just needs to be money ... If there is no money, the needs would not be met - even through marketing. Or if you are educated enough and can run your mind for some business then your needs will be met. Through that, you will earn money, and according to that, you can meet your needs. If you have no money or not educated, then none of your needs will be met. One will tell you to march ahead after beating [you up] if you don't have money." (Sudama Singh, Kurmi)
}

Sudama realizes that equal participation in markets (i.e. acting in action fields) is not always possible. Although one may be theoretically capable of purchasing, and potentially selling anything, such capability requires, using the MAS approach terminology, access to initial endowments (e.g. wealth, education). Other informants mention such endowments as family ties or relationships, while others desire access to a bit more power. Since the inaccessibility of markets reinforces the desire to participate, attaining similitude in participation turns into a dream of bountiful life that ends up being projected onto the future. Therefore, many respondents express strong hope that their children will get 'there', the abode of caste indistinctiveness, by means of education.

\footnotetext{
"In the village, there still are people who will not drink the water we have touched; who will not sit with us for eating or drinking;
} 


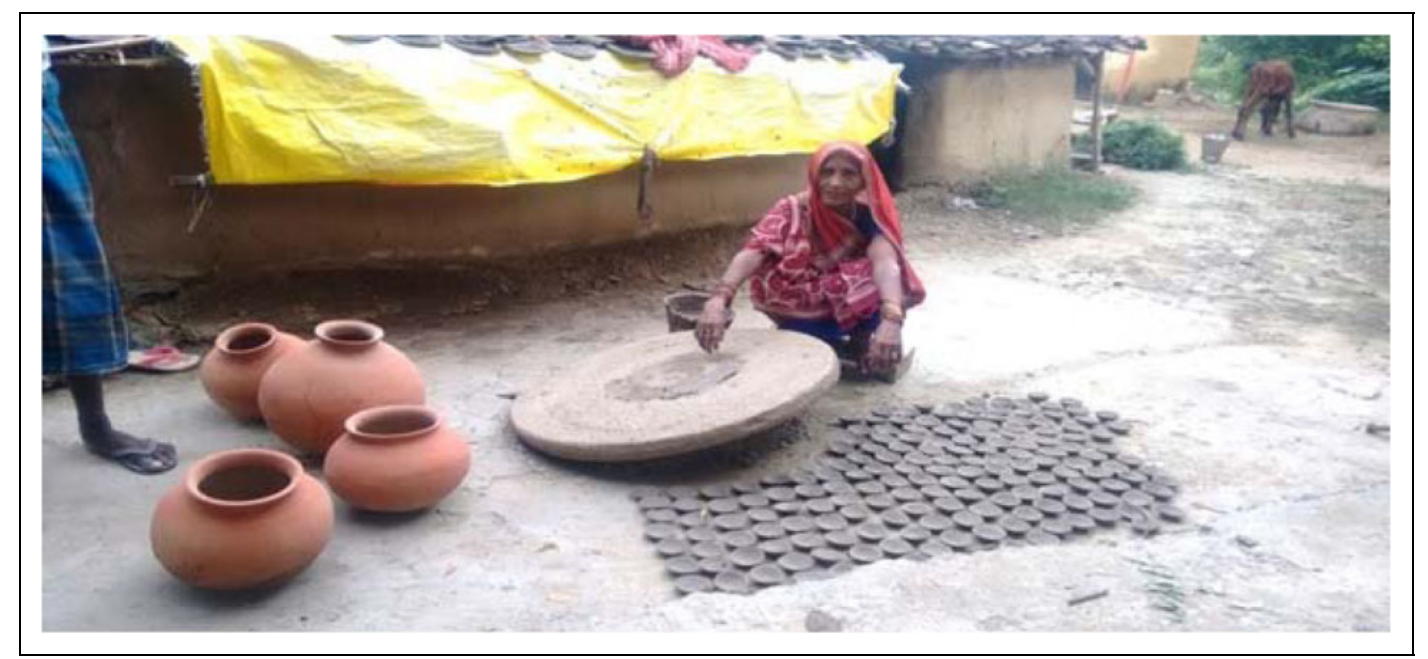

Figure 3. Grassroots market activity in an Indian village: A pottery workshop.

and Brahmin-Thakurs don't allow us inside their homes. They will say that they are from that [high] caste. This is still happening." (Aruna Devi, Chamar)

Aruna points out another hurdle subalterns face in the struggle for market acceptance. The endowments (capital, capabilities, and labor) that they could bring to the table to contribute to value creation are distinguished as "impure", and therefore are seen as an unwelcome contribution. (Figure 3)

There is a famous saying by the Roman Emperor Vespasian pecunia non olet (i.e. money doesn't smell) suggesting that sources from which money/wealth is earned do not affect its worth. However, this is far from being true in the subaltern context. Although participants stress that money attracts respect, they do not mean any kind of money. In fact, money does "smell" according to the informants. Many respondents, despite highlighting the need for more money, stress that it must earn from the sources that are dignified.

"How should be money earned? It should not be that it is from Chori-Chamari or loot. Money should be commensurate to (the type of) work, would not only that be counted? And if it is not there with us the poor, so what will happen?" (Sushil Kumar, Chamar)

"Chori-Chamari" is a phrase in the local language meaning stealing, defraud, and hucksterism. Interestingly, the term itself is related to traditional work associated with the caste Chamar, the cobblers. The informants reported that people demarcate while attaching a strong stigma to certain traditional types of labor and employment, mostly associated with low castes. In fact, some types of menial labor such as public sanitation, recycling, certain types of farming, hide processing, cleaning, or anything to do with things considered "unclean" is despised. Subalterns, when talking about human dignity, tend to commit the same error. They simply accept the mainstream cultural classification of "unclean labor". Hence, the group ends up constructing an inauthentic identity of itself as a reaction to an externally imposed societal view (Kadirov, Varey, and Wolfenden 2013). Such inauthentic acting ends up as shortsighted denial of opportunities which may, in fact, turn into the very rich source of legitimate market income for this group.

Summary. The analysis of the interviews reveals that subalterns, in the hope of transcending beyond the status of symbolic anchoring and attaining "invisibility" to become free from the stigmatized label "lower/impure" in market encounters, act to minimize perceived dissimilitude to the privileged other. In other words, they hope to develop capabilities to enable them to participate within existing systems, thereby dreaming of a spatiotemporal space where their endowments would be deemed valuable as it is the case for the rest of the population. Subalterns dream of escaping their lived reality via joining problematic marketing system processes as the only option to recover dignity. However, the basic form of such problematic structure would remain, requiring more people to instrumentally serve as symbolic anchors for those who eventually succeed attaining indistinction. Hence, we realize that a key capability that the capabilities economy approach overlooks is the ability to transcend beyond individualistic quests including the capacity to develop and maintain alternative dignityenhancing marketing systems.

\section{Interpretive Framework: Subaltern Dignity Experiences}

Subaltern dignity experiences arise as a result of fundamental adaptive changes in marketing systems. As rigid traditional market relations based on orthodox dignification give way to fluid marketization underscored by market power/wealth based dignification, subalternity as a phenomenon in itself and related subaltern experiences increasingly mirror the problematic structure of emerging hybridized marketing systems (Figure 5).

Market dignification as a social mechanism perpetuates unbalanced relations in actions fields and biased evaluation of endowments. Such structural anomalies consistently echo 


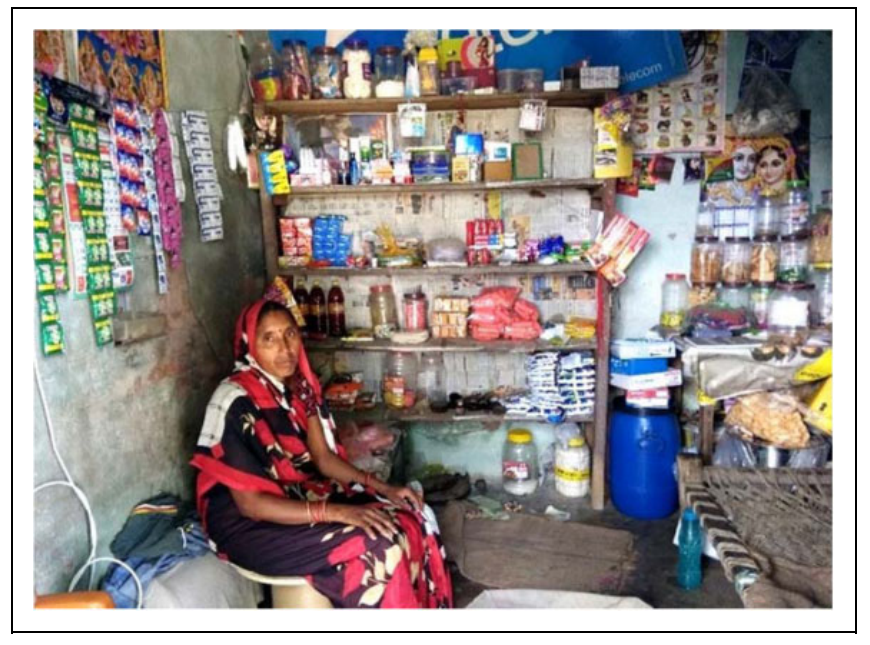

Figure 4. Grassroots market activity in an Indian village: A grocery outlet.

in subalterns' phenomenological lived-in realities as apophatic dignity and dissimilitude minimization experiences. This sort of echoing allows subalterns to continuously problematize dignity, their own and others, as they understand it. In addition, subalterns construct and maintain specific dreams of equal market participation, while making constant attempts to gain access to existing marketing systems. This "in-out" state of being, i.e. dynamic existence in relation to marketing systems, fails to solve the subaltern's dilemma since it requires subalternity as a necessary structural element. We envision a potential way out of this dilemma: nurturing a new type of capability related to constructing potential marketing systems that eschew market-based dignification (refer to the part of Figure 4 marked in red).

\section{Discussion}

\section{Dignity-Enhancing Marketing Systems}

We, through this qualitative research, explore how do potential market system actors become subaltern?; How and why subaltern dignity experiences arise in the context of market relations?; and How is dignity experienced and problematized by subalterns within marketing systems? This study, focusing on "voices-of-subalterns", investigates how this group constructs macromarketing realities through the prism of their daily experiences and in situ sense-making. These experiences echo the contrived nature of existing marketing systems distorted under the impact of dignification metamorphosis generated by deep sociocultural/economic divisions that characterize the Indian countryside.

Our focus on the concept of dignity in interpretation helps us develop a nuanced understanding of subalternity as a unique phenomenon within encompassing marketing systems. First, by focusing on the orthodox-to-marketized dignification shift we realize that subalternity arises as a fundamental, as well as purposeful, marketing system element at the confluence of market and societal forces. Second, we detect that the problematic nature of biased social mechanisms within marketing systems continuously reverberates in citizens' apophatic dignity experiences. Finally, our attention to dignifying practices helped us to see that subalterns make constant attempts to minimize their perceived dissimilitude in order to gain access to existing, albeit problematic, marketing systems.

\section{Assessing BOP and Moral Economy's Potential in Deciphering the Subaltern Quandary}

BoP focuses on harnessing the self-interestedness of powerful market actors to create targeted and customized market offerings for subalterns (Prahalad 2010; Prahalad and Hammond 2002; Hart and Prahalad 2002; Rangan, Chu, and Petkoski 2011). In doing this, the approach aims at combining two potentially conflicting societal welfare outcomes: profit generation and poverty alleviation (Varman, Skalen, and Belk 2012).

The approach has attracted a great deal of criticism (Banerjee and Duflo 2007; Karnani 2012). In general, this criticism was so far based on the following points: 1) the size of the market was unrealistically exaggerated (Karnani 2006, 2012); 2) the dynamic nature of the subaltern markets (e.g. practices) was not taken into account (Lindeman 2012); 3) the approach ignored unequal power relations and information asymmetries that led to the de-politicization of market interventions (Arora and Romijn 2012); 4) it presupposed a top-down approach which advocated an ambitious neo-liberal incursion into hitherto inaccessible markets, while falling short of considering the complexities of subaltern society (Bonsu and Polsa 2011); and 5) the conceptualizations of $\mathrm{BoP}$ relied on the "economistic" view of the subsistence consumer (Karnani 2006) that entailed only a limited understanding of poverty and the specific life conditions of poor consumers (Blocker et al. 2012; Sen 2004; World Bank 2008). Specifically, Varman, Skalen, and Belk (2012) draw on neoliberal governmentality theory to analyze the e-Choupal initiative and related micro practices in rural India. They find that the initiative because it has exclusively been guided by BoP assumptions, led to the further marginalization of subaltern groups whereby the elite greatly benefited from the project while the poor were forcefully excluded.

We develop yet another vantage point for the critique based on situating subalterns within the dignification processes of marketing systems. Our research findings suggest that BoP would be problematic even if subalterns were successfully targeted. The BoP logic is fundamentally antagonistic to subaltern concerns, interests, and experiences. Subalterns make constant attempts to escape their subaltern reality, flee the experiences of anchoring, instrumentalization, and dehumanization which their unique status occupancy entails, and try to minimize their dissimilitude to others. Paradoxically, a targeted BoP offering or scheme would create an opposite symbolic effect, as it would offer a market-based structure through which humiliating experiences can be unreflectively channeled in their morphed forms, while the subaltern group's specific status occupancy is continually affirmed. In fact, a BoP action would 
be like adding fuel to the fire, as it would further facilitate marketized dignification, and thus reinforce the privilegedsubaltern chasm.

The $\mathrm{BoP}$ is designed to relegate subalterns to a passive state within action fields, i.e. the consumers of solutions imposed from the "top". Subalterns dream of markets not only in the sense that they would benefit from them in terms of daily provisioning, but also in terms of maximizing their dignity. Hence, the expected output from a marketing system appears to be not only product assortments as $\mathrm{BoP}$ assumes, but also the symbolic sense of dignity, i.e. opportunities for inclusion, participation, and value creation. We find that in some circumstances, due to dignification dynamics, marketing system assortments are not perceived as neutral. Rather, these assortments become a means of de-dignifying market practices. The paradox of unregulated markets is elitism, i.e. that they may become 'closed' systems designed, maintained, and managed by (and for the benefit of) the elites (Kadirov, Varey, and Wolfenden 2016), "making the country look more and more like islands of California in a sea of sub-Saharan Africa" (Drèze and Sen 2013, p. ix). What the subaltern group wishes is not simply some share in the assortments. Instead, they also wish to access the 'common good' output of the marketing system: being valued and respect.

In contrast, the moral economy approach emphasizes the role of non-market mechanisms in countering the harms of marketization (Polanyi (2001) [1944]). Emphasizing social embeddedness of market relations, Varman and Costa (2008) argue that the "invisible hand of social norms" rather than self-interestedness governs the market system in the Indian countryside. For instance, one of their informants indicates that serving "uncultured" customers would undermine his honor. This "norm of honor" is, in fact, paradoxical, as it is linked to relegating the other to a lower status. We cannot simply assume that traditional non-market mechanisms would, by default, work to offset the negative impact of marketization.

Recent research indicates that supposedly constructive village customs such as gift-giving and communal mutuality may also operate as oppressive systems of domination (Vikas, Varman, and Belk 2015). In the process of maximizing the symbolic power, the elite tends to use social mechanisms to reinforce their privileged position and further humiliate the disenfranchised consumer (Vikas, Varman, and Belk 2015). Therefore, the moral economy approach requires, by design, a common criterion to weigh social mechanisms in terms of their welfare enhancement for various population strata. The capacity for human dignity enhancement can potentially be used as one of such criteria. Moreover, evaluating the e-Choupal initiative, Varman, Skalen, and Belk (2012) show that orthodox arrangements (e.g. the caste system) serve a role of a power structure that restricts the activities of the poor, while the elite enjoys the freedom guaranteed by neoliberal policy making. They note that power relations are inherently imbued in social mechanisms which, instead of correcting markets, enable them to function uninhibitedly while maintaining their inherent biases (e.g. the exclusion of subalterns).

Our findings, while generally supporting this critical view of the moral economy, add a further insight. Subalterns' apophatic dignity experiences testify that specific social mechanisms (e.g. symbolic anchoring, instrumentalization, and dehumanization) are employed within the marketing system to effectuate (Sarasvathy 2001), and then further perpetuate the problematic structure, the process that underlies the seamless metamorphosis of orthodox-to-market dignification. There is neither counter-reaction as assumed by the moral economy perspective nor complete market/power structural separation as proposed by the existing critique.

What we observe in this specific context is that a social mechanism (e.g. dignification) assumes its marketized simulacrum and functions as an integral element of the marketing system. Marketplace dignification underscored by specific practices such as symbolic anchoring arises as a kind of dominant social paradigm (Kilbourne et al. 1997) that is at the heart of how operating marketing systems generate perceived marked-based happiness. Perhaps, problematic social mechanisms require radical transformation based on the broad definition of dignity.

\section{Can the Capabilities Approach Improve Subalterns' Lot?}

The capabilities approach calls for guarantying the provisioning of fundamental functionings (e.g. being free of hunger, being educated) which would increase life choices subalterns have realistic access to (Sen 1985; Nussbaum 2011). Offering unconditional choices to enhance the group's autonomy is directly related to dignity. Nussbaum (2011) emphasizes ten central capabilities which improve personal dignity: life, bodily health, bodily integrity, senses and imagination, emotions, practical reason, affiliation, other species, play, and control over one's environment. She argues that these capabilities represent individual abilities that would allow human beings to live a dignified life. The capabilities approach requires the assessment of whether subalterns have these capabilities and the development of institutions that foster and guarantee them.

Our research indicates that capability assessment would become a complex task as subalterns often fake their various capabilities to minimize their dissimilitude to others. Hence, assessments of poverty that are insensitive to dignity perceptions of the population may yield biased results. On the other hand, the subaltern group may end up valuing only the choices that make sense within the symbolism of existing marketing systems. As they are constantly fantasizing as well as attempting to become equal (i.e. dignified) participants in problematic structures, a key capability - which is not discussed in the existing capability approach literature - appears to be missing. This is the capability related to constructing potential marketing systems (refer to Figure 5) that are broadly inclusive (Acemoglu and Robinson 2013). The capability to set up just marketing systems (not simply markets) implies social mechanisms underscored by the broad conception of dignity, 


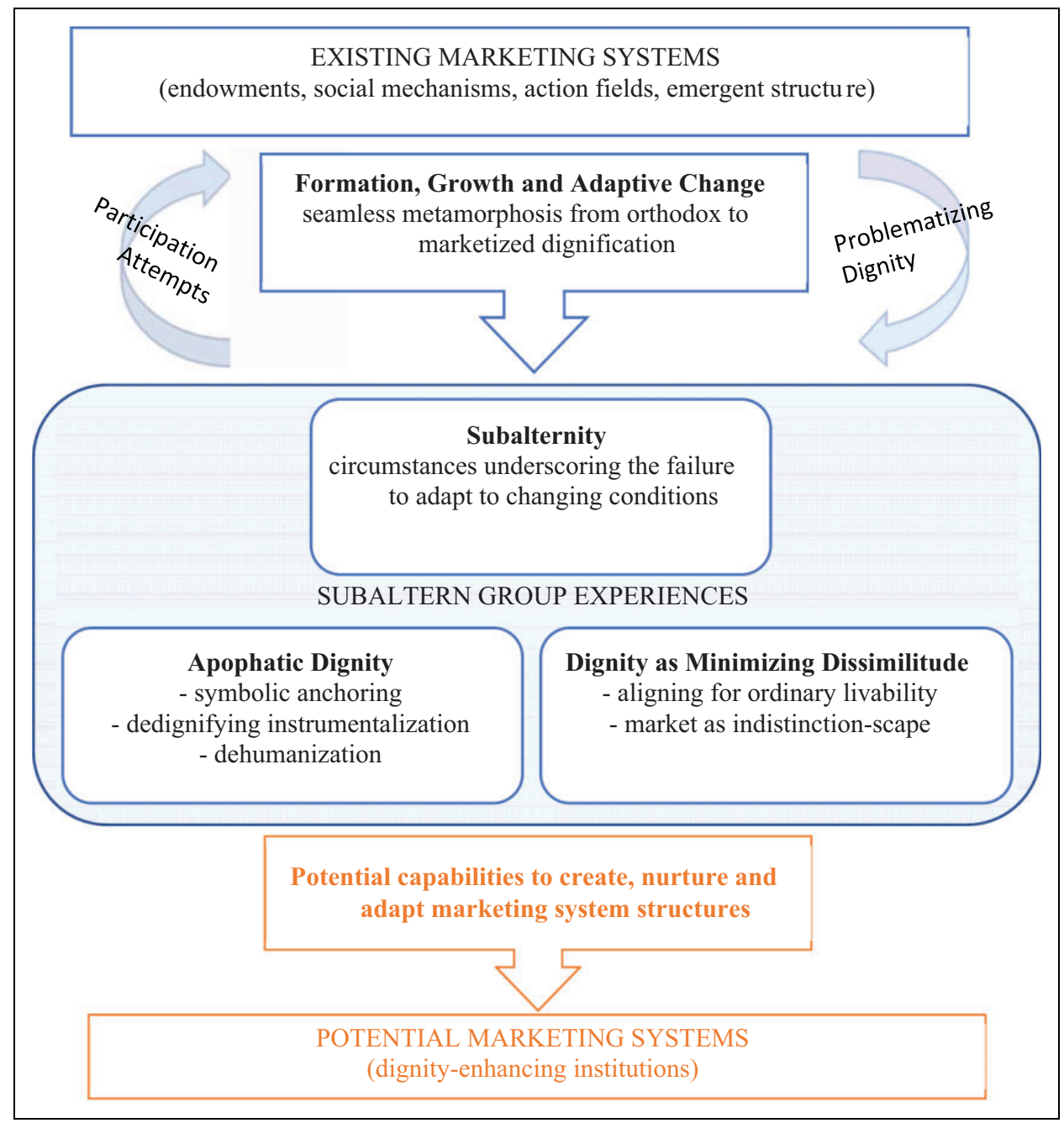

Figure 5. Subaltern dignity experiences in marketing systems.

action fields based on the cooperation of all stakeholders, and continuous calibration of emergent structures through inclusive governance.

Varman and Vikas (2007) call for subaltern empowerment in the production domain as the necessary condition for attaining freedom in consumption. Most problems they list (e.g. low wages, exploitation) are direct consequences of the lack of respect for human worth and labor. However, empowerment would not be effective if archaic dignification were not eschewed. It appears that an excessive focus on narrowlydefined dignification within existing marketing systems dulls a creative focus on self-fulfilling, self-realizing value-creation experiences based on appreciating rich localized resources, although this lack of focus is understandable given extremely dismal circumstances. If creative capabilities are promoted instead, the subaltern group might realize that their current aspirations are flawed. Sustainable community building, rather than individualistic quests, based on small entrepreneurship, creative craftsmanship, and the provision of other localized services linked to natural eco-systems would perhaps be more fulfilling.

\section{Conclusion}

\section{Potential Marketing Systems of Dignity}

This research augments the MAS framework by highlighting the dignity-related symbolism of marketing systems (Layton 2015). It also pertains to the domain of the institutional foundations of marketing systems (Kilbourne et al. 1997), symbolism based marketing system design (Kadirov and Varey 2011), as well as the development school of macromarketing thought (Mittelstaedt et al. 2014). We propose that the development of potential marketing systems must be accompanied by initiatives directed at ensuring dignity for each specialized role and action field within a marketing system.

According to the MAS theory of marketing systems (Layton 2015), marketing systems are formed under the impact of a number of different causal processes including role specialization. Our findings suggest that due to orthodox and marketized dignification some specialized roles within the action fields under focus are normatively relegated to the 'filthy' status despite representing essential value-creating activities (e.g. cleaning, sanitation, waste removal, recycling, some forms of 
farming labor). This leads to the flight of the subaltern group and others from such potentially contributing activities, especially when the potential of relatively well-organized public services and utility systems in the developed countries is well known. Caste-based discrimination practices and their marketized metamorphoses become building blocks of distorted marketing systems, while these social mechanisms are used to enforce de-dignifying market arrangements. The problem might not be in the lack of opportunities or resources, but in the absence of appreciation for particular types of endowments (e.g. labor input).

The importance of respect for work and absorbed passion for a profession, even if it is as mundane as selling fruits off a cart in a street, has been stressed by economic historians (McCloskey 2006). Hence, the subaltern quandary could not be solved by merely creating work opportunities. Symbolic elements must also be manipulated to signal respectfulness. For instance, waste collection systems can be organized in such a way that there is minimum human contact with waste materials, whereby workers are appropriately resourced. Also, such public services can be labeled using more respect-signaling signs such as 'environmental services', or more contextualized signs.

Most importantly, the long-term approach would be to develop respect for various professions, skills, jobs, and work in general among the wider population. For example, the recent study shows that waste collectors, in comparison to other professions, are the most beneficial members of society in the UK creating $£ 12$ of societal value per $£ 1$ wages they receive (Lawlor, Kersley, and Steed 2009). Moreover, the population's macromarketing capability, in other words, knowledge, know-how, skills of initiating and shaping effective marketing systems, will need to be fostered. The subaltern group's current concern appears to be how to transform themselves and their offspring in such a way that their input to existing marketing systems becomes dignified. However, what is needed is knowhow and operant resources on building alternative marketing systems that are based on valuing and rewarding the group's existing skills.

\section{Symbolic Marketing Systems Participation and the Government's Role}

Dignity matters. Transcending beyond its archaic conceptualization in marketing systems is a complex dilemma that requires a societal resolution. In India, archaic dignification seamlessly operates as a new market logic which results in further discrimination, marginalization, and exclusion of subalterns. Yet, subalternity is not simply an externality effect that can be treated via enrolling the same dysfunctional market structure. Rather, it is an emergent structural element of marketing systems (Layton 2015) where subalterns are its symbolic participants. The irony is that subalternity as a structural element is consolidated further as subalterns embrace the existing Dominant Social Paradigm and dream of joining the ranks of the "invisible" other (Kilbourne, McDonagh, and Prothero 1997). On the societal level, the logic "comparatively more consumption equals happiness" which treats others as a symbolic gauge must be eschewed in favor of the "happiness equals genuine concern for others" logic that presupposes respect for human worth.

Dignity is a unique locus of public policy making. Without wisdom-based public interference, as it is seen in the context of subalternity, unfettered markets, as well as non-market mechanisms, might fail to deliver on the promise of respect for humanity. Hence, the government must play an active role in sanctioning and promoting the development of potential dignity-maximizing marketing systems. Focused attempts are to be made to facilitate the development of marketing institutions so that markets can be made just, inclusive, and devoid of demeaning symbolism. Government legislation and local bylaws can create a foundation for vibrant and responsive marketing systems that encourage inclusiveness and participation.

\section{Declaration of Conflicting Interests}

The author(s) declared no potential conflicts of interest with respect to the research, authorship, and/or publication of this article.

\section{Funding}

The author(s) received no financial support for the research, authorship, and/or publication of this article.

\section{Notes}

1. Researchers arranged some token help for participants in this study.

\section{References}

Acemoglu, Daron and James A. Robinson (2013), Why Nations Fail: The Origins of Power, Prosperity, and Poverty. New York: Crown. Adler, Mortimer J. (1967), The Difference of Man and the Difference It Makes. New York: Fordham University Press.

Arora, Saurabh and Henny Romijn (2012), "The Empty Rhetoric of Poverty Reduction at the Base of the Pyramid," Organization, 19 (4), 481-505.

Banerjee, Abhijit V. and Esther Duflo (2007), "The Economic Lives of the Poor," The Journal of Economic Perspectives, 21 (1), 141-67.

Belk, Russell W. (2010), "Sharing," Journal of Consumer Research, 36 (5), 715-34.

Blocker, Christopher P., Julie A. Ruth, Srinivas Sridharan, Colin Beckwith, Ahmet Ekici, Martina Goudie-Hutton, José Antonio Rosa, Bige Saatcioglu, Debabrata Talukdar, Carlos Trujillo, and Rohit Varman (2012), "Understanding Poverty and Promoting Poverty Alleviation Through Transformative Consumer Research," Journal of Business Research, 66 (8), 1195-202.

Bonsu, Samuel K. and Pia Polsa (2011), "Governmentality at the Base-of-the-Pyramid," Journal of Macromarketing, 31 (3), 236-44.

Booth, William J. (1994), "On the Idea of the Moral Economy," American Political Science Review, 88 (3), 653-67.

Borooah, Vani K., Amaresh Dubey, and Sriya Iyer (2007), "The Effectiveness of Jobs Reservation: Caste, Religion and Economic Status in India," Development and Change, 38 (3), 423-45. 
Braun, Virginia and Victoria Clarke (2006), "Using Thematic Analysis in Psychology," Qualitative Research in Psychology, 3 (2), 77-101.

Chaudhuri, Himadri R. (2010), "Everyday Life of the Subaltern Consumers: Contexts, Realities, and Issues for Marketing," The Marketing Review, 10 (3), 259-67.

Chossudovsky, Michel (1997), The Globalization of Poverty: The Impacts of IMF and World Bank Reforms. London, UK: Zed Books.

Clarke, John (2004), Changing Welfare, Changing States: New Directions in Social Policy. London, UK: Sage.

Deaton, Angus and Jean Drèze (2002), "Poverty and Inequality in India: A Re-Examination," Economic and Political Weekly, 37 (36), 3729-48.

Deaton, Angus and Valerie Kozel (2005), "Data and Dogma: The Great Indian Poverty Debate," The World Bank Research Observer, 20 (2), 177-99.

Denzin, Norman (1984), The Research Act. Englewood Cliffs, NJ: Prentice Hall.

Drèze, Jean and A. Amartya Sen (2013), An Uncertain Glory: India and Its Contradictions. London, UK: Allen Lane.

Dumont, Louis (1970), Homo Hierarchicus: The Caste System and Its Implications. Chicago: The University of Chicago Press.

Eckhardt, Giana M. and Humaira Mahi (2012), "Globalization, Consumer Tensions, and the Shaping of Consumer Culture in India," Journal of Macromarketing, 32 (3), 280-94.

Egonsson, Dan (2012), Dimensions of Dignity: The Moral Importance of Being Human. New York: Springer Science and Business Media.

Erlandson, David A., Edward Harris, Barbara L. Skipper, and Steve D. Allen (1993), Doing Naturalistic Inquiry: A Guide to Methods. Newburry Park, CA: Sage.

Fisk, George (1974), Marketing and Ecological Crisis. New York, NY: Harper and Row.

Ghosh, Jayati and C. P. Chandrasekhar (2000), The Market that Failed. New Delhi, India: Leftward.

Granovetter, Mark (1985), "Economic Action and Social Structure: The Problem of Embeddedness," American Journal of Sociology, 91 (3), 481-510.

Guba, Egon and Yvonne Lincoln (1989), Fourth Generation Evaluation. Newbury Park, CA: Sage.

Hammond, Allen L., William J. Kramer, Robert S. Katz, Julia T. Tran, and Courtland Walker (2002), "The Next 4 Billion," Innovations, 2 (1-2), 147-58.

Hart, Stuart and C. K. Prahalad (2002), "The Fortune at the Bottom of the Pyramid," Strategy+ Business, 26 (1), 54-67.

Harvey, David (2007), A Brief History of Neo-liberalism. Oxford, UK: Oxford University Press.

Ito, Takahiro (2009), "Caste Discrimination and Transaction Costs In the Labor Market: Evidence from Rural North India," Journal of Development Economics, 88 (2), 292-300.

Jaiswal, Anand K. and Shruti Gupta (2015), "The Influence of Marketing on Consumption Behaviour at the Bottom of the Pyramid," Journal of Consumer Marketing, 32 (2), 113-24.

Joseph, Sarah (2007), "Neoliberal Reforms and Democracy in India," Economic and Political Weekly, 42 (31), 3213-18.
Kadirov, Djavlonbek and Richard J. Varey (2011), "Symbolism in Marketing Systems," Journal of Macromarketing, 31 (2), 160-71.

Kadirov, Djavlonbek, Richard J. Varey, and Ben Wooliscroft (2013), "Authenticity: A Macromarketing Perspective," Journal of Macromarketing, 34 (1), 73-79.

Kadirov, Djavlonbek, Richard J. Varey, and Sally Wolfenden (2016), "Investigating Chrematistics in Marketing Systems A Research Framework," Journal of Macromarketing, 36 (1), 54-67.

Kant, Immanuel ((2002) [1785]), Groundwork for the Metaphysics of Morals. New Haven, CT: Yale University Press.

Karnani, Aneel (2006), "The Mirage of Marketing to the Bottom of the Pyramid," California Management Review, 49 (4), 90-111.

Karnani, Aneel (2012), "Markets of the Poor: Opportunities and Limits," International Journal of Rural Management, 8 (1-2), 7-17.

Kijima, Yoko (2006), "Caste and Tribe Inequality: Evidence from India, 1983-1999," Economic Development and Cultural Change, 54 (2), 369-404.

Kilbourne, William E., Pierre McDonagh, and Andrea Prothero (1997), "Sustainable Consumption and the Quality of Life: A Macromarketing Challenge to the Dominant Social Paradigm," Journal of Macromarketing, 17 (1), 4-24.

Kolk, Ans, Miguel Rivera-Santos, and Carlos Rufín (2014), "Reviewing a Decade of Research on the Base/ Bottom of the Pyramid (BOP) Concept," Business and Society, 53 (3), 338-77.

Kuch, Hannes (2011), "The Rituality of Humiliation: Exploring Symbolic Vulnerability," in Humiliation, Degradation, Dehumanization, P. Kaufmann, H. Kuch, C. Neuhäuser, and E. Webster, eds. Netherlands: Springer, 37-56.

Kumar, M. (2016a), “Contemporary Relevance of Jajmani Relations in Rural India,” Journal of Rural Studies, 48, 1-10.

Kumar, Rajiv (2016b), "Making Reforms Work for the Common People," Economic and Political Weekly, 51 (29), 51-55.

Kurien, C. T. (1995), Aspects of India's Economy. New Delhi: Orient Longman.

Laczniak, Gene R. and Patrick E. Murphy (2006), "Normative Perspectives for Ethical and Socially Responsible Marketing," Journal of Macromarketing, 26 (2), 154-77.

Lal, Vinay (2001), "Subaltern Studies and Its Critics: Debates over Indian History," History and Theory, 40 (1), 135-48.

Lawlor, Eilis, Helen Kersley, and Susan Steed (2009), A Bit Rich: Calculating the Real Value to Society of Different Professions. London, UK: The New Economics Foundation.

Layton, Roger A. (2009), "On Economic Growth, Marketing Systems, and the Quality of Life," Journal of Macromarketing, 29 (4), 349-62.

Layton, Roger A. (2015), "Formation, Growth, and Adaptive Change in Marketing Systems," Journal of Macromarketing, 35 (3), 302-19.

Lindeman, Sara (2012), "Market Formation in Subsistence Contexts: A Study of Informal Waste Trade Practices in Tanzania and Brazil," Consumption, Markets and Culture, 15 (2), 235-57.

Madheswaran, S. and Paul Attewel (2007), "Caste Discrimination in the Indian Urban Labour Market: Evidence from the National Sample Survey," Economic and Political Weekly, 42 (41), 4146-53. 
Maiorano, D. (2014), "Continuity Amid Change in India's Political Economy: From 'Socialist' to 'Neoliberal' India," Economic and Political Weekly, 49 (9), 44-54.

McCloskey, Deirdre N. (2006), The Bourgeois Virtues: Ethics for an Age of Commerce. Chicago: The University of Chicago Press.

Ministry of Home Affairs, Government of India. (2016, March 1), "Lok Sabha Unstarred Question No 828," (accessed September 15, 2016), [available at http://mha1.nic.in/par2013/par2016-pdfs/ 1s-010316/828.pdf].

Mishra, Lakshmidhar (2012), "History of Labor Rights," Social Change, 42 (3), 335-57.

Mittelstaedt, John D., Clifford J. Shultz, William E. Kilbourne, and Mark Peterson (2014), "Sustainability as Megatrend: Two Schools of Macromarketing Thought," Journal of Macromarketing, 34 (3), 253-64.

Nussbaum, Martha C. (2011), Creating Capabilities: The Human Development Approach. Cambridge, MA: Harvard University Press.

Oliver, Sophie (2011), "Dehumanization: Perceiving the Body as (In)Human," in Humiliation, Degradation, Dehumanization, P. Kaufmann, P. Kuch, C. Neuhauser, and E. Webster, eds. New York, NY: Springer, 85-97.

Patnaik, Prabhat (2007a), "The State Under Neo-liberalism," Social Scientist, 35 (1/2), 4-15.

Patnaik, Prabhat and C. P. Chandrasekhar (1995), "Indian Economy Under Structural Adjustment," Economic and Political Weekly, 30 (47), 3001-13.

Patnaik, Utsa (2004), “The Republic of Hunger," Social Scientist, 32 (9/10), 9-35.

Patnaik, Utsa (2007b), "Neoliberalism and Rural Poverty in India," Economic and Political Weekly, 42 (30), 3132-50.

Patnaik, Utsa (2013), "Poverty Trends in India 2004-05 to 2009-10," Economic and Political Weekly, 48 (40), 43-58.

Peñaloza, Lisa and Alladi Venkatesh (2006), "Further Evolving the New Dominant Logic of Marketing: From Services to the Social Construction of Markets," Marketing Theory, 6 (3), 299-316.

Poland, B. D. (2002), "Transcription Quality," in Handbook of Interview Research: Context and Method, J. F. Gubrium and J. A. Holstein, eds. Thousand Oaks, CA: Sage, 629-49.

Polanyi, Karl ((2001) [1944]), The Great Transformation: The Political and Economic Origins of Our Time. Boston, MA: Beacon Press.

Prahalad, C. K. (2010), The Fortune at the Bottom of the Pyramid: Eradicating Poverty through Profits, 5th ed. Upper Saddle River, NJ: Wharton School Publishing.

Prahalad, C. K. and Allen L. Hammond (2002), What Works: Serving the Poor, Profitably: A Private Sector Strategy for the Global Digital Opportunity. Washington, DC: World Resources Institute.

Rangan, V. Kasturi, Michael Chu, and Djorjiji Petkoski (2011), "The Globe: Segmenting the Base of the Pyramid," Harvard Business Review, 89 (6): 1-6.

Ray, Rajat Kanta (2011), "Bazaar: Pulsating Heart of the Indian Economy," in The Oxford India Anthology of Business History, M. M. Kudaisya, ed. New Delhi: Oxford University Press, 3-48.

Rice, Pranee Liamputtong and Douglas Ezzy (1999), Qualitative Research Methods: A Health Focus. Melbourne: Oxford University Press.
Rosen, Michael (2012), Dignity: Its History and Meaning. Cambridge, MA: Harvard University Press.

Roy, Tirthankar (2012), India in the World Economy: From Antiquity to the Present. New Delhi: Cambridge University Press.

Sainath, Palagummi (2009), "Ways of Seeing," (accessed July 18, 2016), [available at Seminar: http:/www.india-seminar.com/ 2009/595/595_p_sainath.htm].

Sarasvathy, S. D. (2001), "Causation and Effectuation: Toward a Theoretical Shift from Economic Inevitability to Entrepreneurial Contingency," The Academy of Management Review, 26 (2), 243-63.

Schiller, Friedrich (2005), "On Grace and Dignity," in Schiller's 'on Grace and Dignity' in Its Cultural Context: Essays and a New Translation, Jane Veronica Curran, Christophe Fricker, and Friedrich Schiller, eds., pp. 123-170 Rochester, NY: Camden House.

Schwandt, Thomas A. (1994), "Constructivist, Interpretivist Approaches To Human Inquiry," in Handbook of Qualitative Research, N. K. Denzin and Y. S. Lincon, eds. Thousand Oaks, CA: Sage, 118-37.

Sen, Abhijit (2004), "Poverty and Inequality in India," Economic and Political Weekly, 39 (38), 4247-63.

Sen, Amartya (1984), Resources, Values, and Development. Oxford, UK: Basil Blackwell.

Sen, Amartya (1985), "Wellbeing, Agency, and Freedom: The Dewey Lectures 1984," Journal of Philosophy, 82 (4), 169-221.

Sen, Amartya (1999), Development as Freedom. New York: Knopf.

Sen, Amartya (2004), "How Does Culture Matter?," in Culture and Public Action, V. Rao and M. Walton, eds. Stanford CA: Stanford University Press, 37-58.

Shrivastava, Aseem and Asishs Kothari (2014), Churning the Earth: The Making of Global India. New Delhi: Penguin Viking.

Singh, Ramendra (2015), "Poor Markets: Perspectives from the Base of the Pyramid," Decision, 42 (4), 463-66.

Smith, Paul (2007), Primitive America: The Ideology of Capitalist Democracy. Minneapolis: University of Minnesota Press.

Sole, Nagendra A. (2014), "Public Policy for Rural Employment in Neo-Liberal Era: A Study of MGNREGA in Rajasthan, India," Public Policy and Administration Research, 4 (12), 69-74.

Spivak, Gayatri C. (1988), "Can the Subaltern Speak?," in Marxism and the Interpretation of Culture, C. Nelson and L. Grossberg, eds. Urbana: University of Illinois Press, 271-313.

Srinivas, M. N. (2003), "An Obituary on Caste as a System," Economic and Political Weekly, 38 (5), 455-59.

Srivastava, Ravi S. (2005), Bonded Labor in India: Its Incidence and Pattern. Geneva, Switzerland: International Labour Office.

Swaminathan, Madhura (2000), Weakening Welfare: The Public Distribution of Food in India. New Delhi: LeftWord Books.

Tellis, Winston (1997), "Application of a Case Study Methodology," The Qualitative Report, 3 (3), 1-19.

Thorat, Sukhadeo (2002), "Oppression and Denial: Dalit Discrimination in the 1990s," Economic and Political Weekly, 37 (6), 572-78.

Thorat, Sukhadeo (2010), "Caste, Exclusion, and Marginalised Groups in India: Dalit Deprivation in India," in Education for Sustainable Development: Challenges, Strategies, and Practices in a Globalizing World, A. Nikolopoulou, T. Abraham, and F. Mirbagheri, eds. New Delhi: Sage, 3-27. 
Thorat, Sukhadeo and Paul Attewell (2007), "The Legacy of Social Exclusion: A Correspondence Study of Job Discrimination in India," Economic and Political Weekly, 42 (41), 4141-45.

Richard J. Varey and Michael Pirson, Eds. (2014), Humanistic Marketing. Basingstoke, UK: Palgrave Macmillan.

Varman, Rohit and Russell W. Belk (2008), "Weaving a Web: Subaltern Consumers, Rising Consumer Culture, and Television," Marketing Theory, 8 (3), 227-52.

Varman, Rohit and Russell W. Belk (2012), "Consuming Postcolonial Shopping Malls,” Journal of Marketing Management, 28 (1-2), 62-84.

Varman, Rohit and Janeen A. Costa (2008), "Embedded Markets, Communities and the Invisible Hand of Social Norms," Journal of Macromarketing, 28 (2), 141-56.

Varman, Rohit, Per Skalen, and Russell W. Belk (2012), "Conflicts at the Bottom of the Pyramid: Profitability, Poverty Alleviation, and Neo-liberal Governmentality," Journal of Public Policy and Marketing, 31 (1), 19-35.

Varman, Rohit and Ram M. Vikas (2007a), "Freedom and Consumption: Toward Conceptualizing Systemic Constraints for Subaltern Consumers in a Capitalist Society," Consumption, Markets, and Culture, 10 (2), 117-31.

Varman, Rohit and Ram M. Vikas (2007b), "Rising Markets and Failing Health: An Inquiry into Subaltern Health Care Consumption under Neoliberalism," Journal of Macromarketing, 27 (2), 162-72.

Vikas, Ram M. and Rohit Varman (2007), "Erasing Futures: Ethics of Marketing an Intoxicant to Homeless Children," Consumption, Markets, and Culture, 10 (2), 189-202.

Vikas, Ram M., Rohit Varman, and Russell W. Belk (2015), "Status, Caste, and Market in a Changing Indian Village," Journal of Consumer Research, 42 (3), 472-98.

Viswanathan, Madhubalan, Anju Seth, Roland Gau, and Avinish Chaturvedi (2009), "Ingraining Product-Relevant Social Good into Business Processes in Subsistence Marketplaces: The Sustainable Market Orientation," Journal of Macromarketing, 29 (4), 406-25.

Viswanathan, Madhubalan, Srinivas Sridharan, Robin Ritchie, Srinivas Venugopal, and Kiju Jung (2012), "Marketing Interactions in Subsistence Marketplaces: A Bottom-Up Approach to Designing
Public Policy,” Journal of Public Policy and Marketing, 31 (2), 159-77.

Weinberger, Michelle F. and Melanie Wallendorf (2012), "Intracommunity Gifting at the Intersection of Contemporary Moral and Market Economies," Journal of Consumer Research, 39 (1), 74-92.

World Bank (2008), World Development Indicators. Washington, DC: The World Bank.

\section{Author Biography}

Sujit Raghunathrao Jagadale is a doctoral student at the Institute of rural Management Anand (IRMA), India. His research interests include marketing systems theory, business strategies in the subsistence marketplaces, processes of market institutionalization and, commercial surrogacy. He writes teaching cases on market creations in the excluded markets. These are published by leading case publishing houses, globally.

Djavlonbek Kadirov (PhD, University of Waikato) is a marketing lecturer at the School of Marketing and International Business, Victoria University of Wellington, New Zealand. Djavlonbek's research interests include marketing systems theory, symbolism in marketing systems, sustainable marketing, and marketing morality. His research has appeared in journals such as the Journal of Macromarketing, Journal of Marketing Management, Journal of Business Research, Journal of Brand Management, Consumption Markets \& Culture, and Journal of Customer Behaviour. Djavlonbek (along with Richard Varey and Ben Wooliscroft) is the winner of the George Fisk Award for the Best Conference Paper at the 2013 Macromarketing Conference.

Debojyoti Chakraborty, a post-graduate from Institute of Rural Management Anand, is a development practitioner. He is currently working as a Programme Officer with Samaj Pragati Sahyog(SPS) in the central province of India. In that capacity he trying to scale up marginal farmers' producer organization. 